\title{
Evolution of mitochondrial genomes in Baikalian amphipods
}

\author{
Elena V. Romanova', Vladimir V. Aleoshin²,3, Ravil M. Kamaltynov' ${ }^{1}$, Kirill V. Mikhailov²,3, Maria D. Logacheva 2,3, \\ Elena A. Sirotinina', Alexander Yu. Gornov ${ }^{5}$, Anton S. Anikin ${ }^{5}$ and Dmitry Yu. Sherbakov ${ }^{1,6^{*}}$ \\ From The International Conference on Bioinformatics of Genome Regulation and StructurelSystems Biology (BGRSISB-2016) \\ Novosibirsk, Russia. 29 August-2 September 2016
}

\begin{abstract}
Background: Amphipods (Crustacea) of Lake Baikal are a very numerous and diverse group of invertebrates generally believed to have originated by adaptive radiation. The evolutionary history and phylogenetic relationships in Baikalian amphipods still remain poorly understood. Sequencing of mitochondrial genomes is a relatively feasible way for obtaining a set of gene sequences suitable for robust phylogenetic inferences. The architecture of mitochondrial genomes also may provide additional information on the mechanisms of evolution of amphipods in Lake Baikal.

Results: Three complete and four nearly complete mitochondrial genomes of Baikalian amphipods were obtained by high-throughput sequencing using the Illumina platform. A phylogenetic inference based on the nucleotide sequences of all mitochondrial protein coding genes revealed the Baikalian species to be a monophyletic group relative to the nearest non-Baikalian species with a completely sequenced mitochondrial genome - Gammarus duebeni. The phylogeny of Baikalian amphipods also suggests that the shallow-water species Eulimnogammarus has likely evolved from a deep-water ancestor, however many other species have to be added to the analysis to test this hypothesis.

The gene order in all mitochondrial genomes of studied Baikalian amphipods differs from the pancrustacean ground pattern. Mitochondrial genomes of four species possess 23 tRNA genes, and in three genomes the extra tRNA gene copies have likely undergone remolding. Widely varying lengths of putative control regions and other intergenic spacers are typical for the mitochondrial genomes of Baikalian amphipods.
\end{abstract}

Conclusions: The mitochondrial genomes of Baikalian amphipods display varying organization suggesting an intense rearrangement process during their evolution. Comparison of complete mitochondrial genomes is a potent approach for studying the amphipod evolution in Lake Baikal.

\section{Background}

Ancient freshwater lakes are the birthplaces of very diverse and mostly endemic biota. Their eco-systems are «natural laboratories of evolution» that offer insights into many evolutionary topics, attracting continuous attention of the scientific community and advancing the elucidation of the speciation mechanisms [1,2]. About ten of the contemporary freshwater lakes existed for longer than one million years. Among them, Lake Baikal is

\footnotetext{
*Correspondence: dysh007@gmail.com

'Laboratory of Molecular Systematics, Limnological Institute, Siberian Branch

of Russian Academy of Sciences, Irkutsk 664033, Russian Federation

${ }^{6}$ Faculty of Biology and Soil Studies, Irkutsk State University, Irkutsk 664003,

Russian Federation

Full list of author information is available at the end of the article
}

the oldest (reviewed in [1-4]). The age of Lake Baikal is estimated by different authors to be in the range of 25 to 30 million years $[5,6]$.

Similarly to other ancient giant lakes, a greater part of the huge diversity of animals inhabiting Lake Baikal belongs to the species flocks [7]. These diverse groups of monophyletic species are believed to evolve in the confines of the lake through adaptive radiation in sympatry $[2,8,9]$, although geographic isolation is possible in some cases [10-12].

Amphipods are the most diverse group of Baikalian invertebrates (more than 350 described species). They are extremely diverse morphologically and have a wide range of ecological specificities $[13,14]$. 
Most of Baikalian amphipod species have evolved in the confines of Lake Baikal, although some of them have later spread to other water bodies in Eurasia [13, 14]. The only Holarctic species inhabiting shallow bays of Lake Baikal is Gammarus lacustris Sars, 1864 [14, 15]. Also Gammarus dabanus Takhteev et Mekhanikova, 2000, an endemic species from the mountain streams of Khamar-Daban ridge, was found at the edge of Baikal near the estuaries [16]. The discovery and description of all amphipod species from Lake Baikal is still far from approaching completion (i.e. [12, 16-19]). The work on the revision of their higher level taxonomy is still in progress [13, 14, 17, 19-27]. According to the most modern revision by Kamaltynov [17] all Baikalian amphipod species belong to 76 genera and eleven families, ten of which are autochthonous: Carinogammaridae Tachteev, 2000, Crypturopodidae Kamaltynov, 2001, Macrohectopodidae Sowinsky, 1915, Micruropodidae Kamaltynov, 1999, Baikalogammaridae Kamaltynov, 2001, Ommatogammaridae Kamaltynov, 2009, Acanthogammaridae Garjajeff, 1901, Eulimnogammaridae Kamaltynov, 1999, Pachyschesidae Kamaltynov, 1999, Pallaseidae Tachteev, 2001.

Application of molecular phylogenetic approaches allowed to refine the taxonomy of Baikalian amphipods and to outline the main trends of their evolution, specifically their phylogenetic position relative to the nonBaikalian amphipod taxa. It was shown that at the very beginning of the diversification Baikalian amphipods had split into at least two major lineages delineated by their ecological and morphological traits [28-32]. This observation could also be explained by two independent colonizations of Lake Baikal. Several groups have shown that the ancestors of the extant Baikalian amphipods were closely related to the ancestors of the Holarctic species of Gammarus Fabricius, 1775 [28, 30-34].

Englisch et al. (2003) showed that Baikalian species Parapallasea lagowskii (Dybowsky, 1874) was «nested within genus Gammarus» [33]. In the study by McDonald et al. performed on 32 species of Baikalian amphipods and 29 non-Baikalian species only species belonging to the family Micruropodidae clustered together with Gammarus [30]. An early study by Sherbakov et al. based on partial 18S rRNA sequences showed close relationship of the two Baikalian lineages to different species of Gammarus [28]. This was later confirmed in the detailed study by Hou and Sket, which utilized more genetic markers and sampled more species of Gammaridae [32]. One lineage of Baikalian amphipods was found to be a sister group to the "Oriental Gammarus clade", the other one was closer to the "Eurasian clade" [32]. Molecular phylogeny also revealed inconsistencies in the current taxonomy of Baikalian amphipods. Genera Acanthogammarus Stebbing, 1899 and Pallasea Bate, 1862 were shown to be polyphyletic $[11,28,35]$.
Majority of the previous molecular studies of evolutionary history and taxonomy of Baikalian amphipods are impeded by insufficient statistical support of the most important clades $[28,30,35,36]$. The presence of poorly resolved clades might be explained both by insufficient length of sequences used and by their low mutational rate (e.g.18S rDNA) [29, 35]. Unfortunately, more recent works aimed at resolving the complicated relations within Gammarus included only a few Baikalian species or did not address their phylogenetic relationship [31, 32, 37, 38]. Therefore, further study of Baikalian amphipods is necessary to elucidate their phylogeny.

In this study we use nucleotide sequences of completely sequenced mitochondrial genomes (mitogenomes) for the evolutionary inferences and clarification of the taxonomy of Baikalian amphipods. The ten studied species appear to form a single clade relative to Gammarus duebeni Lilljeborg, 1852. We also perform a detailed comparative structural analysis of amphipods mitochondrial genomes and find an unexpectedly high degree of their length variation and extensive gene rearrangements.

\section{Results and Discussion}

\section{Mitochondrial genomes organization}

We obtained three complete and four nearly complete sequences of mitochondrial genomes from Baikalian amphipod species. Information about animals sampling sites, sequences lengths, numbers of reads, GenBank accession numbers, etc. of currently studied Baikalian amphipod species and that of previously published ones is presented in Table 1. Acanthogammarus victorii (Dybowsky, 1874) and Garjajewia cabanisii (Dybowsky, 1874) have incomplete non-coding regions sequences due to their low complexity and the presence of repeats (the 51-mer tandem repeats in the control region (CR) of $A$. victorii and the $\mathrm{CR}$ sequence duplication in the mitochondrial genome of G. cabanisii) that have prevented automatic assembly process. Mitochondrial genomes of Crypturopus tuberculatus (Dybowsky, 1874) and Linevichella vortex (Dybowsky, 1874) also lack various parts of the coding sequences due to the difficulties in amplification of these regions. The sizes of complete mitochondrial genomes range from 14,370 to 18,114 b.p., which is within the range of mitogenomes of other amphipods (14,113 to 18,424 b.p.). The AT content varies from 62.24 to $68.96 \%$ for completely sequenced mitochondrial genomes and from 57.45 to $64.86 \%$ for partially sequenced ones (Table 2). In general this is compatible with the values of other known complete amphipod mitogenomes (64.03-76.03\%), although the AT content of Brachyuropus grewingkii (62.24\%) was found to be the lowest within amphipods [39-47].

All completely sequenced mitochondrial genomes of Baikalian amphipods have strong negative values of GC- 
Table 1 Summary of the Baikalian amphipod data presented in the study

\begin{tabular}{|c|c|c|c|c|c|c|c|c|c|}
\hline Species & $\begin{array}{l}\text { Sampling site, } \\
\text { coordinates }\end{array}$ & $\begin{array}{l}\text { Ecological } \\
\text { features: depth } \\
\text { of habitat, } \\
\text { armament, } \\
\text { nutrition }\end{array}$ & $\begin{array}{l}\text { DNA template } \\
\text { type, number } \\
\text { of paired reads }\end{array}$ & $\begin{array}{l}\text { Mean } \\
\text { coverage of } \\
\text { mitogenome }\end{array}$ & $\begin{array}{l}\text { Mito } \\
\text { genome } \\
\text { size, b.p. }\end{array}$ & $\begin{array}{l}\text { AT- } \\
\text { skew }\end{array}$ & $\begin{array}{l}\text { GC- } \\
\text { skew }\end{array}$ & $\begin{array}{l}\text { GenBank } \\
\text { nos. }\end{array}$ & References \\
\hline Acanthogammarus victorii & $\begin{array}{l}\text { Listvyanka, } \\
51^{\circ} 51^{\prime} 30^{\prime \prime} \mathrm{N}, \\
104^{\circ} 50^{\prime} 37^{\prime \prime} \mathrm{E}\end{array}$ & $\begin{array}{l}\text { 1.5-90 m., } \\
\text { spiny, } \\
\text { predator/ } \\
\text { scavanger }\end{array}$ & $\begin{array}{l}\text { total DNA, } \\
6.3 \mathrm{M}\end{array}$ & $40 x$ & $17,424^{\mathrm{a}}$ & 0.027 & -0.251 & KX341962 & $\overline{\text { This study }}$ \\
\hline Brachyuropus grewingkii & $\begin{array}{l}\text { Estuary of } \\
\text { Buguldeyka } \\
\text { river, } 52^{\circ} 28^{\prime} \mathrm{N}, \\
106^{\circ} 06^{\prime} \mathrm{E}-52^{\circ} 28^{\prime} \mathrm{N}, \\
106^{\circ} 05^{\prime} \mathrm{E}\end{array}$ & $\begin{array}{l}\text { 100-1380 m., } \\
\text { (usually deeper } \\
\text { than } 300 \text { m.) } \\
\text { spiny, predator }\end{array}$ & $\begin{array}{l}\text { total DNA, } \\
6.4 \mathrm{M}\end{array}$ & $12 x$ & 17,118 & 0.003 & -0.307 & KP161875 & [105] \\
\hline Crypturopus tuberculatus & $\begin{array}{l}\text { Estuary of Anga } \\
\text { river, } 52^{\circ} 46^{\prime} 40^{\prime \prime} \\
N, 106^{\circ} 34^{\prime} 60^{\prime \prime} \mathrm{E}\end{array}$ & $\begin{array}{l}1.5-99 \mathrm{~m}_{.,} \\
\text {tuberous, } \\
\text { detritophagous }\end{array}$ & $\begin{array}{l}\text { mitochondrial } \\
\text { DNA amplicons, } \\
59,961\end{array}$ & $901 \times$ & $13,864^{\mathrm{b}}$ & -0.070 & -0.013 & KX341963 & This study \\
\hline Eulimnogammarus cyaneus & $\begin{array}{l}\text { Sukhoi Ruchey, } \\
51^{\circ} 38^{\prime} 48^{\prime \prime} N \text {, } \\
103^{\circ} 45^{\prime} 14^{\prime \prime} \mathrm{E}\end{array}$ & $\begin{array}{l}0-3.5 \mathrm{~m} ., \\
\text { smooth, } \\
\text { phytophagous }\end{array}$ & $\begin{array}{l}\text { mitochondrial } \\
\text { DNA amplicons, } \\
541,283\end{array}$ & $7665 x$ & 14,370 & -0.019 & -0.251 & KX341964 & This study \\
\hline Eulimnogammarus verrucosus & $\begin{array}{l}\text { Bol'shie Koty, } \\
51^{\circ} 54^{\prime} 11.67^{\prime \prime} \mathrm{N} \\
105^{\circ} 04^{\prime} 07.61^{\prime \prime} \mathrm{E}\end{array}$ & $\begin{array}{l}\text { 0-12 m., } \\
\text { (usually 0-3 m.) } \\
\text { smooth, } \\
\text { phytophagous }\end{array}$ & $\begin{array}{l}\text { total DNA, } \\
352.7 \mathrm{M}\end{array}$ & $1000 x$ & 15,314 & -0.007 & -0.238 & KF690638 & [71] \\
\hline Eulimnogammarus vittatus & $\begin{array}{l}\text { Sukhoi Ruchey, } \\
51^{\circ} 38^{\prime} 48^{\prime \prime} N \\
103^{\circ} 45^{\prime} 14^{\prime \prime} \mathrm{E}\end{array}$ & $\begin{array}{l}\text { 0-30 m., } \\
\text { (usually 0-3 m.) } \\
\text { smooth, } \\
\text { phytophagous }\end{array}$ & $\begin{array}{l}\text { total DNA, } \\
4.6 \mathrm{M}\end{array}$ & $21 \times$ & 15,534 & -0.014 & -0.222 & KM287572 & [104] \\
\hline Garjajewia cabanisii & $\begin{array}{l}\text { Estuary of } \\
\text { Buguldeyka } \\
\text { river, } 52^{\circ} 28^{\prime} \mathrm{N}, \\
106^{\circ} 06^{\prime} \mathrm{E}-52^{\circ} 28^{\prime} \mathrm{N}, \\
106^{\circ} 05^{\prime} \mathrm{E}\end{array}$ & $\begin{array}{l}80-1250 \text { m., } \\
\text { (usually deeper } \\
\text { than } 200 \text { m.) } \\
\text { spiny, predator }\end{array}$ & $\begin{array}{l}\text { total DNA, } \\
7.5 \mathrm{M}\end{array}$ & $24 x$ & $17,576^{\mathrm{a}}$ & -0.002 & -0.286 & KX341965 & This study \\
\hline Gmelinoides fasciatus & $\begin{array}{l}\text { Sukhoi Ruchey, } \\
51^{\circ} 38^{\prime} 31^{\prime \prime} N \\
103^{\circ} 46^{\prime} 03^{\prime \prime} \mathrm{E}\end{array}$ & $\begin{array}{l}\text { 0-192 m. } \\
\text { (usually 0-5 m.), } \\
\text { tuberous, } \\
\text { phytophagous/ } \\
\text { euryphagous }\end{array}$ & $\begin{array}{l}\text { total DNA, } \\
7.4 \mathrm{M}\end{array}$ & $14 \times$ & 18,114 & -0.001 & -0.303 & KX341966 & This study \\
\hline Linevichella vortex & $\begin{array}{l}\text { Listvyanka, } \\
51^{\circ} 51^{\prime} 12^{\prime \prime} N \\
104^{\circ} 51^{\prime} 48^{\prime \prime} \mathrm{E}\end{array}$ & $\begin{array}{l}0-88 \text { m., (usually } \\
1-2 \text { m.) smooth, } \\
\text { phytophagous }\end{array}$ & $\begin{array}{l}\text { mitochondrial } \\
\text { DNA amplicons, } \\
13,319\end{array}$ & $132 x$ & $11,444^{\mathrm{b}}$ & -0.027 & -0.223 & KX341967 & This study \\
\hline Pallaseopsis kesslerii & $\begin{array}{l}\text { Estuary of Anga } \\
\text { river, } 52^{\circ} 46^{\prime} 40^{\prime \prime} \\
\mathrm{N}, 106^{\circ} 34^{\prime} 60^{\prime \prime} \mathrm{E}\end{array}$ & $\begin{array}{l}\text { 1-61 m., } \\
\text { slightly spiny, p } \\
\text { hytophagous }\end{array}$ & $\begin{array}{l}\text { mitochondrial } \\
\text { DNA amplicons, } \\
14,144\end{array}$ & $154 \times$ & 15,759 & 0.010 & -0.182 & KX341968 & This study \\
\hline
\end{tabular}

Bold numbers indicate incomplete sequences

a mitochondrial genome with an incomplete non-coding part

a mitochondrial genome with incomplete sequences of both coding and non-coding parts

$M$ denotes million reads

skew (prevalence of $\mathrm{C}$ over $\mathrm{G})$ on the $(+)$ strand $(-0.30$ to -0.18) and their AT-skew (prevalence of A over $\mathrm{T}$ ) varies from -0.02 to 0.01 (Table 1 , Additional files 1 and 2). Species with partial mitochondrial genome sequences have GC-skew from -0.25 to -0.01 and AT-skew from -0.07 to +0.02 . The unequal nucleotide content between two strands is typical for mitochondrial DNA. This is a consequence of an asymmetric mutational process that affects the $\mathrm{A}$ and $\mathrm{C}$ nucleotides during the replication and transcription $[48,49]$.
Complete sequences of Baikalian amphipod mitochondrial genomes contain 13 protein coding genes, two rRNA genes and from 22 to 23 tRNA genes, a CR and intergenic spacers of different number and lengths (Fig. 1, annotations of studied mitochondrial genomes are in Additional file 3).

\section{Protein-coding genes order}

All completely sequenced Baikalian amphipod mitochondrial genomes possess a typical set of 13 protein- 
Table 2 Comparison of mitogenomic characteristics of Baikalian amphipods

\begin{tabular}{|c|c|c|c|c|c|c|c|c|c|c|c|c|}
\hline \multirow[t]{2}{*}{ Species } & \multicolumn{2}{|l|}{ Genome } & \multicolumn{2}{|l|}{ PCGs } & \multicolumn{2}{|l|}{ rRNAs } & \multicolumn{2}{|l|}{ tRNAs } & \multicolumn{2}{|c|}{ Putative CRs } & \multicolumn{2}{|c|}{ Intergenic spacers } \\
\hline & $\begin{array}{l}\text { Length, } \\
\text { b.p. }\end{array}$ & AT $\%$ & $\begin{array}{l}\text { Length, } \\
\text { b.p. }\end{array}$ & AT $\%$ & $\begin{array}{l}\text { Length, } \\
\text { b.p. }\end{array}$ & AT $\%$ & $\begin{array}{l}\text { Length, } \\
\text { b.p. }\end{array}$ & AT $\%$ & $\begin{array}{l}\text { Length, } \\
\text { b.p. }\end{array}$ & AT $\%$ & $\begin{array}{l}\text { Length, } \\
\text { b.p. }\end{array}$ & AT $\%$ \\
\hline Acanthogammarus victorii & 17,424 & 59.28 & 11,043 & 57.01 & 1616 & 63.68 & 1360 & 64.34 & 1390 & 70.86 & 2035 & 56.86 \\
\hline Brachyuropus grewingkii & 17,118 & 62.24 & 11,056 & 60.20 & 1608 & 66.36 & 1304 & 65.41 & 1264 & 73.26 & 1852 & 61.56 \\
\hline Crypturopus tuberculatus & 13,864 & 57.45 & 10,803 & 56.53 & 798 & 63.28 & 1078 & 62.15 & - & - & 1207 & 57.91 \\
\hline Eulimnogammarus cyaneus & 14,370 & 67.59 & 11,047 & 66.78 & 1607 & 71.81 & 1300 & 66.69 & 181 & 77.90 & 268 & 75.37 \\
\hline Eulimnogammarus verrucosus & 15,314 & 68.96 & 11,022 & 66.63 & 1602 & 69.54 & 1335 & 67.42 & 437 & 83.30 & 872 & 76.63 \\
\hline Eulimnogammarus vittatus & 15,534 & 67.42 & 11,050 & 65.59 & 1606 & 71.30 & 1373 & 67.30 & 1053 & 79.01 & 491 & 72.51 \\
\hline Garjajewia cabanisii & 17,576 & 64.86 & 11,052 & 62.67 & 1605 & 66.98 & 1367 & 65.47 & 1212 & 76.07 & 2324 & 67.60 \\
\hline Gmelinoides fasciatus & 18,114 & 65.87 & 11,448 & 63.29 & 1594 & 69.01 & 1348 & 66.47 & 235 & 81.28 & 3863 & 70.88 \\
\hline Linevichella vortex & 11,444 & 64.51 & 9813 & 64.15 & 538 & 67.84 & 829 & 64.29 & - & - & 296 & 72.97 \\
\hline Pallaseopsis kesslerii & 15,759 & 63.10 & 11,035 & 61.13 & 1597 & 64.87 & 1361 & 67.52 & 340 & 80.59 & 1800 & 70.67 \\
\hline
\end{tabular}

Bold numbers indicate incomplete sequences

coding genes (PCGs). PCGs of each species have the same transcriptional polarity as in the pancrustacean ground pattern [50] (Fig. 1), however the order of PCGs has been altered relative to the ground pattern in the mitochondrial genomes of three species under study. Pallaseopsis kesslerii (Dybowsky, 1874) has a translocation of the nad1 gene, C. tuberculatus possesses translocation of nad5, cytB, nad1, cox3, nad3, nad4, nad4l, nad6, Gmelinoides fasciatus (Stebbing, 1899) has translocations of nad1, nad5, nad4, nad4l, nad6 and cytB (Fig. 1). These re arrangements have never been observed in other amphipod species.

The only feature in common among the amphipods with the altered gene order is that they are relatively shallow water dwellers (Table 1) belonging to the Micruropus flock [35]. However, there are other shallow water amphipods in the dataset which have an unaltered order of mitochondrial genes.

In the non-Baikalian amphipods one may also find deviations from the pancrustacean ground pattern. Onisimus nanseni G.O. Sars, 1900 has nad6 and cytB translocation, in some species of Metacrangonyx Chevreux, 1909 cytB is inverted [39, 40, 45], the species of Caprella Lamarck, 1801 have nad4, nad4l, nad6 translocations and nad5 inversion. Gene order in the species belonging to Pseudoniphargus Chevreux, 1901 differs from the pancrustacean ground pattern and is variable within the genus. $P$. daviui Jaume, 1991 has nad1 translocation and P.sorbasiensis Notenboom, 1987 has nad6, cytB translocation.

Non-Baikalian amphipods with rearranged PCGs relative to the pancrustacean ground pattern are distant from each other taxonomically (up to a superfamily level) as well as ecologically. Among the species with an altered gene order there are two genera of freshwater stygobionts: Palearctic genus Metacrangonyx (superfamily Hadzioidea) and Nearctic genus Pseudoniphargus (superfamily Allocrangonyctoidea) [34], Arctic marine species O.nanseni (superfamily Lysianassoidea) [42] and some species of Caprella (superfamily Caprelloidea) inhabiting warm seas around the world [51, 52]. Still, amphipods carrying the unchanged ground pattern are at least equally taxonomically and ecologically diverse. Parhyale hawaiiensis (Dana, 1853) (superfamily Talitroidea) is a marine species distributed in north Atlantic [53], Bahadzia jaraguensis Jaume and Wagner, 1998 (superfamily Hadzioidea) is a stygobiontic species that was found in the caves of West Indian and Caribbean regions [54, 55], G. duebeni (superfamily Gammaroidea) is a North Atlantic distributed species [56], Gondogeneia antarctica (Chevreux, 1906) (superfamily Calliopioidea) is a South Antarctic species [57].

It seems that the changes in the gene order of Baikalian as well as non-Baikalian amphipods can not be directly correlated with any meaningful environmental parameter. Similarly, although it is possible that some lineages are more prone to reshuffling of their mitochondrial genes then the others, they do not appear to be phylogenetically clustered. Obviously, further careful investigation with a more comprehensive dataset is necessary to resolve the ancestral pattern of Baikalian amphipod mitochondrial genomes.

\section{Base composition bias in protein-coding genes}

The GC-skew values were measured for all protein coding genes similarly to the measure of strand composition bias [58]. Mitochondrial genomes of most Baikalian amphipod species studied here have negative GC-skew in PCGs that are located on the $(+)$ strand. PCGs encoded on the (-) strand, on the contrary, have positive GC-skew (Fig. 2, Additional file 2). Such strand bias is typical for most mitochondrial genomes in Malacostraca [42, 59]. However, in C. tuberculatus, the composition bias was found to be noticeably lower than in the other 

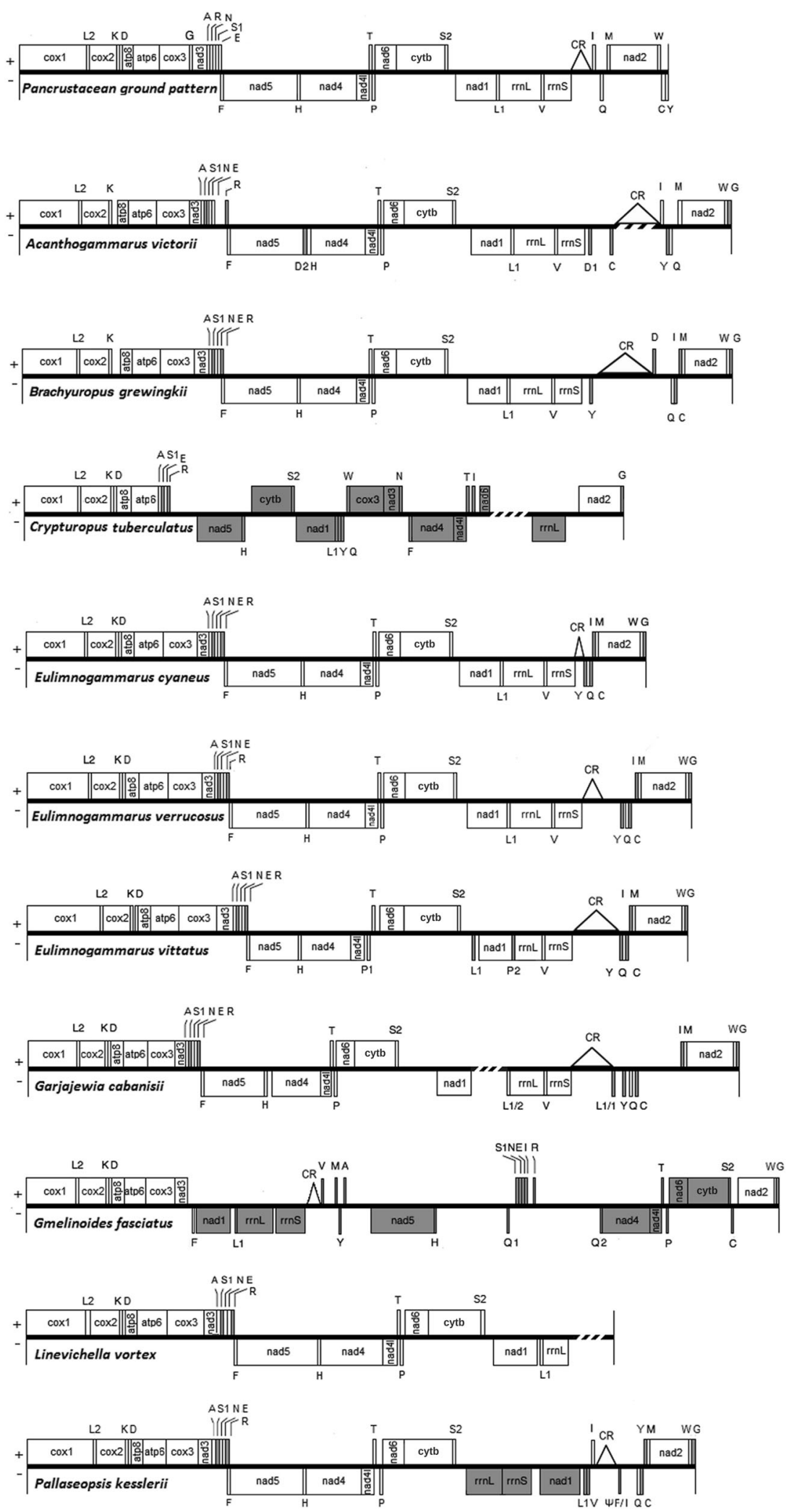

Fig. 1 (See legend on next page.) 
(See figure on previous page.)

Fig. 1 Organization of mitochondrial genomes of Baikalian amphipods in comparison to the pancrustacean ground pattern. Genes on the $(+)$ strand are located above the line, whereas genes coded on the (-) strand are below the line. Transfer RNAs genes are labeled by their single-letter amino acid code. Oblique strokes in some genomes denote unknown areas that were not sequenced due to technical difficulties. Gene features with altered location in comparison to the pancrustacean ground pattern are shown in grey color. Location of a putative CR sequence of B.grewingkii has been changed from the one inferred in the previously published article by Romanova et al. [105]

species. The GC-skew values of the $(+)$ strand PCGs vary from -0.11 to +0.14 and of the $(-)$ strand PCGs GC-skew values vary from +0.02 to +0.09 (Fig. 2). In the nad 3 and nad6 genes the strand bias is reversed and thus the GC-skew is positive.

The strand bias reversion was previously detected in the mitochondrial genomes of several different invertebrate species such as Katharina tunicata (Mollusca), Florometra serratissima (Echinodermata), Argiope amoena (Chelicerata), Aleurochiton aceris, Bemisia tabaci, Campanulotes bidentatus, Thrips imaginis, Bothriometopus macrocnemis, Cotesia vestalis, Neomaskellia andropogonis, Tetraleurodes acacia ect. (Hexapoda), Ligia oceanica, Hutchinsoniella macracantha, Tigriopus californicus, Lepeophtheirus salmonis, Calanus hyperboreus, Argulus americanus,
Procambarus clarkii, Corallianassa couitierei, Nihonotrypaea japonica, Cambaroides similis, Homarus gammarus ect. (Crustacea) [43, 45, 49, 58]. Within amphipods the reversed strand bias was found in the mitochondrial genomes of Metacrangonyctidae species [45]. As previously suggested by Hassanin et al., 2005, the strand reversion can happen due to the reversion of one or several genes relative to the CR or alternatively, it could be explained by the reversion that includes the CR [49]. We did not succeed in sequencing the $\mathrm{CR}$ of $C$. tuberculatus and thus we can not conclude which scenario is more likely in this case. Still, taking into account the relatively low values of GC skew of the majority of protein coding mitochondrial genes in this organism, one may speculate that the reversion is a relatively recent event on the evolutionary time scale [49].
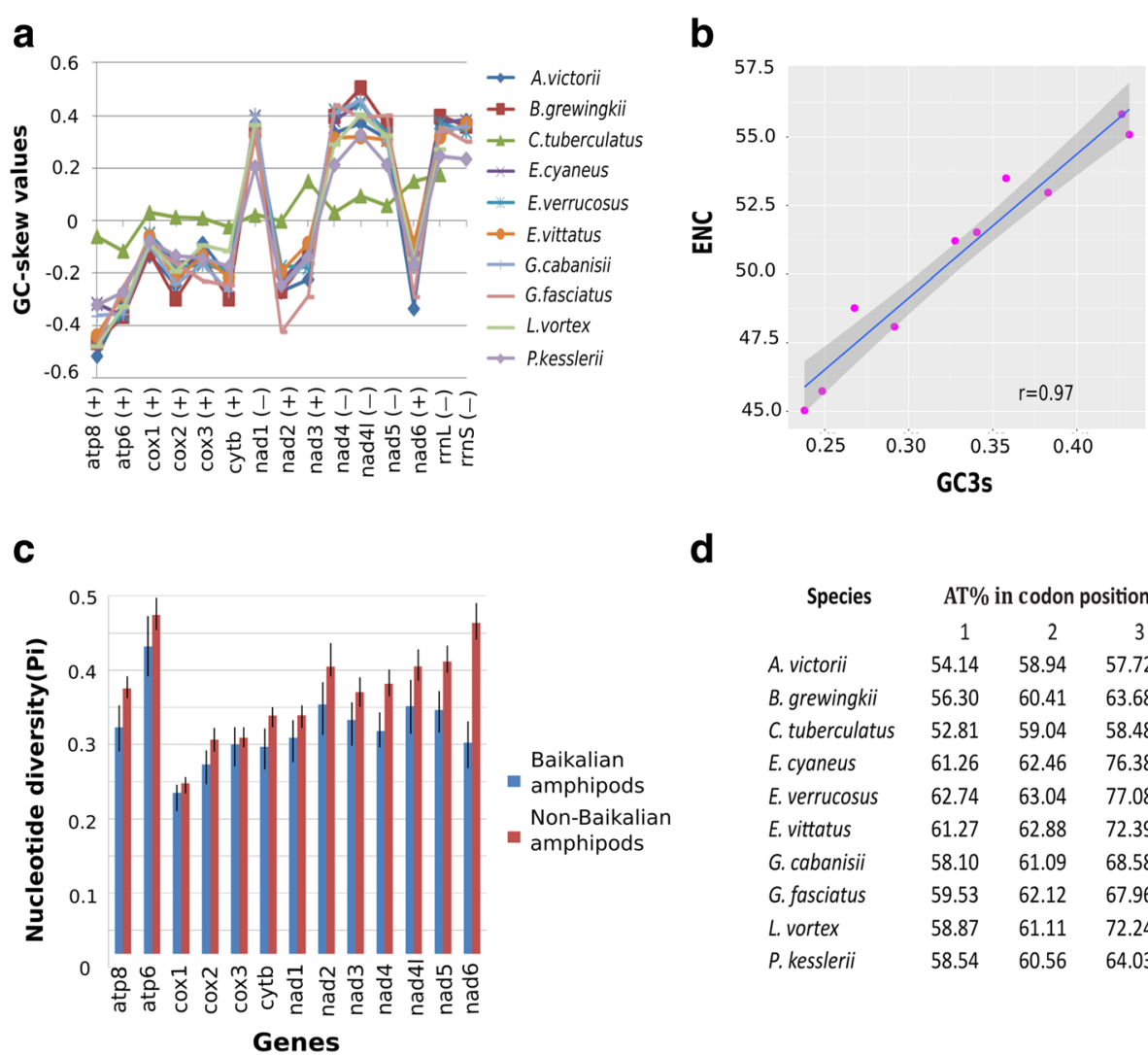

d

\begin{tabular}{lccc}
\multicolumn{1}{c}{ Species } & \multicolumn{3}{c}{ AT\% in codon positions } \\
& 1 & 2 & 3 \\
A. victorii & 54.14 & 58.94 & 57.72 \\
B. grewingkii & 56.30 & 60.41 & 63.68 \\
C. tuberculatus & 52.81 & 59.04 & 58.48 \\
E. cyaneus & 61.26 & 62.46 & 76.38 \\
E. verrucosus & 62.74 & 63.04 & 77.08 \\
E. vittatus & 61.27 & 62.88 & 72.39 \\
G. cabanisii & 58.10 & 61.09 & 68.58 \\
G. fasciatus & 59.53 & 62.12 & 67.96 \\
L. vortex & 58.87 & 61.11 & 72.24 \\
P. kesslerii & 58.54 & 60.56 & 64.03
\end{tabular}

Fig. 2 Statistical data for PCGs and ribosomal genes in mitochondrial genomes of Baikalian amphipods. a GC-skew values of PCGs and ribosomal genes. (+) marks genes coded by the positive strand, (-) marks genes coded by the negative strand. $\mathbf{b}$ An illustration of a positive correlation between the effective number of codons (ENC) and the GC content at the third codon position (GC3s) in Baikalian amphipods. c Nucleotide diversity (Pi) values for PCGs of Baikalian and non-Baikalian amphipods. $\mathbf{d}$ AT content (\%) in three codon positions in PCSs of Baikalian amphipods 
Taxa with a reversed strand bias should be taken into phylogenetic analysis with caution as they tend to promote long branch attraction artifacts [49].

\section{AT content in protein-coding genes and codon usage}

The AT content of completely sequenced PCGs varies from $57.01 \%$ (in A.victorii) to $66.78 \%$ (in Eulimnogammarus cyaneus (Dybowsky, 1874)) (Table 2). The PCGs of $A$. victorii have the lowest AT content among entirely sequenced mitochondrial genomes of amphipods. Codon positions in mitochondrial PCGs were noted to have an unequal AT content. Mitochondrial genomes studied here have the lowest AT content at the first codon position, a slightly higher AT content at the second position and the highest AT content at the third codon position (Fig. 2). The A. victorii and C.tuberculatus species, however, have the highest AT content at the second codon position in their PCGs, and the lowest at the first codon position (Fig. 2).

Codon usage analysis in Baikalian amphipods revealed the presence of all codon types typical for the invertebrate mitochondrial code (Additional file 4). Along with the regular start codons (ATA and ATG), the unusual ones (ATT, ATC, TTG and GTG) were predicted to initiate mitochondrial PCGs. Presence of unusual start and stop codons is generally typical for mitochondrial genomes [60]. Some PCGs of the investigated genomes possess truncated stop codons $(\mathrm{T})$ that are presumably completed after a post-transcriptional polyadenylation [61] (Additional file 3).

In all currently studied genomes the most frequently used codons are TTT (Phe) (5.40 to 7.05\%) and TTA (Leu) (4.69 to 8.72\%). Also some of the more frequent codons include ATT (Ile) (2.93 to 5.54\%), ATA (Met) (3.69 to 6.07\%) (Additional file 4). In non-Baikalian amphipods these four codons are also among the most abundant ones. Bias toward the AT-rich codons is typical for many arthropods [62].

The Effective Number of Codons (ENC) [63] in Baikalian amphipods varies widely, ranging from 45.04 in Eulimnogammarus verrucosus (Gerstfeldt, 1858) to 55.67 in C.tuberculatus (Fig. 2). These values exceed slightly the ENC in other amphipod species, which range from 36.47 to 49.74 . A strong positive correlation $(r$ $=0.97$ ) between ENC and GC content at the third codon position was found in mitochondrial genomes of Baikalian amphipods (Fig. 2). The ENC in all sequenced genomes increases with the decrease of AT content in protein coding genes.

\section{Nucleotide diversity analysis}

Nucleotide diversity (Pi) was estimated for two groups of protein-coding genes, the first one encompasses the Baikalian amphipod species, the second one contains nonBaikalian species (see species list in Additional file 5) (Fig. 2).
These data may be useful for designing new molecular markers for phylogenetic inferences of amphipods. The patterns of nucleotide diversity within mitochondrial genes in both groups were nearly identical, with lower values for genes of Baikalian amphipods. This may be due to the much higher evolutionary span of the non-Baikalian amphipod species in comparison to the Baikalian amphipods. Indeed, all Baikalian amphipods belong to a single superfamily Gammaroidea, while the rest of analyzed amphipods represent superfamilies Hadzioidea, Allocrangonyctoidea, Lysianassoidea, Caprelloidea, Talitroidea, Gammaroidea, Calliopioidea.

In both groups the $\operatorname{cox} 1$ sequences have the smallest values of diversity $(0.23 \pm 0.01$ for Baikalian species, and $0.24 \pm 0.01$ for non-Baikalian ones), whereas the atp 8 appears to be the most variable $(0.43 \pm 0.03$ for Baikalian species and $0.47 \pm 0.01$ for non-Baikalian ones) (Fig. 2). The highest difference in the nucleotide diversity between Baikalian and non-Baikalian species was noted in the nad6, which might be caused by the lack of a complete sequence from L.vortex. Other studies dedicated to animal mitochondrial genomes also revealed the cox genes to be the most conserved and the atp genes to be the most variable [45, 64-68]. However, there are animal groups with the different patterns of nucleotide variability distribution within protein coding genes of their mitochondrial genomes $[69,70]$. It seems that the pattern of nucleotide diversity is a lineage specific feature.

On the basis of the data of all available Baikalian amphipod mitochondrial genomes it is possible to predict which genes are more suitable for different phylogenetic applications in this taxonomic group. The most variable genes (atp8, nad2, nad4l, nad5, nad6) can be utilized as markers for species level phylogeny and population studies. Alternatively, sequences of the least variable mitochondrial cox genes may be suitable for deep phylogeny (families and higher taxa) investigations.

\section{Transfer RNA genes}

From 22 to 23 tRNA genes were identified in the completely sequenced mitogenomes of Baikalian amphipod species. The locations of tRNA genes are highly variable and all studied mitochondrial genomes have tRNA genes with altered positions relative to the pancrustacean ground pattern (Fig. 1).

The secondary structures of 213 mitogenome-encoded tRNAs ranging from 49 to 64 b.p. in length and including those of E.verrucosus [71] were predicted for the analysis (Additional file 6). Most of the predicted tRNAs possess the expected clover-leaf structures, however some of them have aberrant structures. The tRNA-Ser (UCU) lacks the DHU arm in all studied species. The DHU arm is also missing in the tRNA-Val of B.grewingkii, A.victorii, E.cyaneus, and G.cabanisii, in the tRNASer (UGA) of G.fasciatus and L.vortex, and in the tRNA- 
Tyr of G.fasciatus. The tRNA-Gln lacks the T $\psi \mathrm{C}$ arm in all studied species except for C.tuberculatus. The T $\psi \mathrm{C}$ arm is also absent in the tRNA-Thr of G.fasciatus and in the tRNA-His and tRNA-Pro of P.kesslerii (Additional file 6).

The presence of tRNAs with aberrant structures was found to be typical for crustaceans [39, 41-45, 47, 72-76] and can also be seen in other invertebrates [77, 78]. The presence of aberrant tRNAs in mitochondrial genomes is usually explained either by selection towards minimization of the mitochondrial genome [77] or by replication slippage [79].

In four out of ten studied mitogenomes the additional tRNA gene copies are found along with the standard set of 22 tRNA genes. A copy of trnP is found in Eulimnogammarus vittatus (Dybowsky, 1874), trnL1 in G.cabanisii, trnQ in G. fasciatus and trnD in A. victorii (Fig. 1, Additional files 3 and 6). The copies of tRNA-Pro, tRNA-Leu1 and tRNA-Asp possess the standard cloverleaf structure. In G. fasciatus a clover-leaf structure is seen in one tRNA-Gln copy (Q2), whereas the other copy (Q1) lacks the $\mathrm{T} \psi \mathrm{C}$ arm (Additional file 6). P.kesslerii also has an additional tRNA adhering to a typical clover-leaf structure, which however has four bases at the presumed anticodon site. The nucleotides in the middle of the anticodon loop may correspond to either Phe or Ile depending on the exact position of the anticodon. An abnormal anticodon suggests that this copy is a pseudogene $(\psi \mathrm{F} / \mathrm{I})$ (Additional file 6).

The presence of additional tRNA genes was noted in many mitochondrial genomes of both vertebrate and invertebrate species. If the duplications occurred recently both copies are either identical or very similar in the primary sequence [80-83]. The copies maintain functionality if they retain some conserved elements of their secondary structure [84]. One of the two copies may subsequently undergo elimination. The vestiges of such copies that accumulated substitutions are identified as pseudogenes [85, 86]. Another possible mechanism involves the switch of tRNA identity as the consequence of a point mutation in the anticodon. This mechanism was called tRNA remolding by Cantatore et al. [87].

While the trnL1 genes of G.cabanisii share $75.00 \%$ identity pointing to their origin from a single trnL1 gene, the tRNA duplicates in other amphipods may have switched their identities: one of the two $\operatorname{trn} P$ genes in $E$. vittatus has $78.68 \%$ identity with the trnL1, in G. fasciatus a copy of $\operatorname{trn} Q$ has $70.00 \%$ identity with the $\operatorname{trn} H$ gene, and in A. victorii a copy of $\operatorname{trnD}$ gene has $67.21 \%$ identity with the $\operatorname{trn} H$ gene. It is likely that the additional tRNA genes of E. vittatus, G. fasciatus and A. victorii have been undergone remolding.

Evidence of tRNA remolding was found in mitochondrial genomes of different groups, including Porifera [88-91], Mollusca [92, 93], Echinodermata [87], Arthropoda $[43,91]$, Chordata $[94,95]$. It was recently shown that the remolding event of Trp (UCA) to Gly (UCC) took place in the ancestor of amphipods [91]. Additional tRNA copies found in the mitogenomes of Baikalian amphipods illustrate different stages of the rearrangement process.

\section{Ribosomal RNA genes}

The rRNA genes in mitochondrial genomes of all studied amphipods are located on the (-) strand. In two out of eight mitochondrial genomes with the completely sequenced coding portion (G.fasciatus and P.kesslerii) the rRNA genes have altered positions in comparison to the pancrustacean ground pattern [50] (Fig. 1, Additional file 3). Rearrangements in the mitochondrial genome involving ribosomal RNA genes or/and PCGs occur much less frequently than those involving only tRNA-coding genes [96-98], thus they are called «major rearrangements» [98]. The rearrangements of rRNA genes and PCGs might potentially affect the effectiveness of replication and transcription of mitochondrial genomes.

The length of completely sequenced Baikalian amphipods' rrnL genes varies from 976 to 984 b.p., and the $r r n S$ gene length varies from 618 to 630 b.p. (Additional file 7). The lengths of rRNA genes in Baikalian amphipods appear to be slightly smaller than those in previously sequenced amphipod mitochondrial genomes [40-42, 44-47]. The AT content ranges from 64.50 to $73.75 \%$ in the $r r n L$ genes, and from 62.38 to $70.90 \%$ in the $r r n S$ genes respectively (Additional file 7). The GC-skew calculations for rRNA genes give highly positive values (from 0.23 to 0.39 for completely sequenced genes) that are comparable to the values calculated for PCGs encoded on the (-) strand (Additional file 7).

\section{Control region and intergenic spacers}

Mitochondrial genomes of Baikalian amphipods have varying numbers and lengths of non-coding regions (Additional file 3). Control region (CR) is the most important non-coding part involved in replication and transcription of the mitochondrial DNA [99]. For identification of a putative CR we searched features typically associated with such regions in invertebrates (poly-T stretch, tandemly repeated sequences, hairpin structures, AT-rich sequences (Additional file 1) [49, 58, 99-103].

In the mitochondrial genome of E. cyaneus a putative $\mathrm{CR}$ is a 181 b.p sequence between the $r r n S$ gene and the trnY-trnQ-trnC-trnI-trnM-nad2 gene cluster. A similar $\mathrm{CR}$ location was also observed in the previously published mitochondrial genomes of E.vittatus (1053 b.p.) [104] and E.verrucosus (473 b.p.) [71] and also in the mitochondrial genome of G. duebeni [44] (Fig. 1, Additional file 3).

Mitochondrial genomes of A.victorii and B.grewingkii [105] possess large non-coding sequences between the rrnS and $n a d 2$ genes. These sequences are interrupted by several tRNA genes. A putative CR in A.victorii is located 
between the locus containing a 13-T stretch and the trnI gene. This region was not sequenced completely, however all features typical for a $\mathrm{CR}$ were found in the partial sequence of the 1390 b.p. long locus. A putative CR in B.grewingkii is a 1264 b.p. long stretch between the 11-T locus and the $\operatorname{trn} D$ gene (Fig. 1, Additional file 3).

In the mitochondrial genome of G.cabanisii the CR is located between the rrnS gene and one of the duplicated trnL1 (trnL1/1) and measures 1212 b.p. in length. (Fig. 1, Additional file 3). Additionally we found traces of a second CR-like sequence located between the nad2 gene and the trnL1/2-rrnL-trnV-rrnS gene cluster. This region was not sequenced in its entirety, only the regions of 102 b.p. and 232 b.p. corresponding to its flanks were sequenced. The 102 b.p. region has a $98.03 \%$ identity with the corresponding region of the original CR, whereas the 232 b.p. region has a $65.60 \%$ identity with the other flank of the original CR (Additional file 8). It is likely that the latter region has undergone degeneration after the duplication. Without the complete sequence it is difficult to estimate the time of duplication and the exact sequence of events that led to the appearance of the second CR or speculate about its possible function. Thus we annotated these sequences simply as non-coding regions. The CR duplications were observed in mitochondrial genomes of some invertebrates, including ticks [106, 107], ostracods [108], sea cucumbers [109], katydids etc. [110]. Amphipods Caprella mutica Schurin, 1935 and Caprella scaura Templeton, 1836 also possess highly identical duplicated CRs in their mitochondrial genomes $[41,43]$.

The position of CR between the $\mathrm{rrnS}$ and nad2 genes in the mitochondrial genomes is typical for some other amphipods: G. duebeni [44], O. nanseni [42], G. antarctica [46], several species of Pseudoniphargus [47] and for the pancrustacean ground pattern as well [50], although the adjacent tRNA genes are often different.

The mitochondrial genome of P.kesslerii has a large non-coding sequence between the nad1 and nad2 genes that is separated by a few tRNA genes and one pseudo tRNA gene. A 340 b.p. sequence located between the $10-\mathrm{T}$ locus and the pseudo tRNA gene $(\psi \mathrm{F} / \mathrm{I})$ was defined as a CR (Fig. 1, Additional file 3).

The mitochondrial genome of G. fasciatus possesses two large non-coding regions: one between the $r r n S$ and nad5 genes, the other between the nad5 and nad4 genes. Both of these regions are interrupted with several tRNA genes. A 235 b.p. region between the $\operatorname{rrnS}$ and $\operatorname{trn} V$ was identified as a CR. All other non-coding regions were annotated as intergenic spacers (Fig. 1, Additional file 3).

It is notable that while most features typical for the CRs are found in the corresponding regions in the majority of sequenced mitochondrial genomes of Baikalian amphipods, the mitogenomes of E. cyaneus and A.victorii only possess tandem repeats.
Variation in the CR location was found in other amphipod species with an altered protein-coding and ribosomal RNA gene order. In the mitochondrial genomes of species from the Metacrangonyx genus the CR sequences were identified between the $r r n S$ and $c y t B$ genes [39, 40, 45]. In C. mutica and C. scaura [41, 43] the first $C R$ is located between the nad6 gene and the $\operatorname{trn} C-c y t B$ gene cluster, and the second $C R$ is located between the nad4l-trnP and the trnI-trnM-trnY-trnQ-nad2 gene clusters. The lengths of $\mathrm{CR}$ sequences in nonBaikalian amphipods also vary significantly from 25 b.p. in M. goulmimensis to 1626 b.p. in G. duebeni [40-42, 44-47]. Furthermore, it was previously shown that this feature varies considerably even between individuals of the same species. Such CR length variation was noted in Metacrangonyx longipes Chevreux, 1909 (26 and 40 b.p.) and Metacrangonyx goulmimensis Messouli, Boutin and Coineau, 1991 (25 and 471 b.p.) [40, 45]. Thus, the variable location and length of CR sequences in mitochondrial genomes of the Baikalian amphipod species is in concordance with the characteristics of CRs in other amphipods and invertebrates in general.

The number of intergenic spacers in completely sequenced mitochondrial genomes of Baikalian amphipods varies from 9 to 21 and their total length varies from 268 to 3863 b.p. (Table 2, Additional file 3). Three Baikalian amphipods with entirely sequenced mitochondrial genomes (B.grewingkii, P.kesslerii, and G.fasciatus) possess the largest portions of intergenic spacers which take up $10.80,11.42$, and $21.32 \%$ of their complete mitochondrial genomes length. Within the currently sequenced nonBaikalian amphipods only G. antarctica [46] has a comparable length of the non-coding intergenic spacers (4354 b.p. in total). The presence of large and numerous intergenic spacers in some mitochondrial genomes studied here may be an evidence of former duplication events [111].

\section{Distinct features of Baikalian amphipod mitochondrial genomes}

Structural analysis of Baikalian amphipod mitochondrial genomes identified several features that differ in most of the studied mitogenomes. Alterations in gene order, strand bias reversion, presence of additional tRNA genes and large non-coding regions as well as a CR duplication indicate intense rearrangement processes, which have occurred during the evolution of Baikalian amphipods. Such rearrangements are usually a result of two major mechanisms, i.e. duplication and subsequent loss of mitochondrial genome regions [112, 113] and intramitochondrial recombination [114]. It is likely that different number and type of rearrangements led to the observed patterns of gene order and variance in the non-coding regions in the mitochondrial genomes of Baikalian amphipods. To decipher the mechanisms behind the appearance of every 
pattern and to predict an ancestral pattern for the mitogenomes of Baikalian amphipods a further careful investigation with a more comprehensive dataset is necessary.

\section{Phylogenetic inference}

For morphological identification of Baikalian amphipod species in our study we used the most modern taxonomy [17]. This taxonomy become a result of successive revision of previous ones [13, 20-22, 24, 26, 27]. Since new families were introduced in the course of recent revisions of Baikalian amphipods, some species and genera were renamed and thus the species list differs from the one given in the previous publications $[28,30$, $35,36]$. To make the phylogenetic results of our work comparable with previous studies we considered them in the context of contemporary taxonomic system that combined all taxonomy alterations [17].

The phylogenetic analyses of amphipod species based on 13 concatenated mitochondrial protein coding gene sequences using Bayesian Inference (BI) resulted in a wellsupported tree. The Baikalian species in the BI tree form a monophyletic group and the amphi-Atlantic amphipod species G. duebeni is the nearest outgroup to the Baikalian clade (Fig. 3).
The previous phylogenetic inferences based on the cox3 gene fragment [36], 18S rRNA and the cox1 gene fragments $[28,35]$ as well as on a combined set of molecular data ( $r r n L$ and $18 \mathrm{~S}$ rRNA, cox1 genes fragments) and morphological characters [30] and the most recent study, which involved four molecular markers (cox1, EF$1 \alpha, 18 \mathrm{~S}$ and $28 \mathrm{~S}$ rRNA) [32], revealed that different species of a genus Gammarus were included into a clade of Micruropodidae family. The phylogenetic trees derived in those studies had low support in many nodes. Utilization of 13 protein coding genes of the mitochondrial genome helped us to obtain a better supported tree of Baikalian amphipods in comparison with the ones described in previous molecular studies. The relatively small number of taxa sampled in our study does not allow us to rule out the possibility that the Baikalian clade might still be split into two or more independent lineages if more species are added to the analysis, particularly if G. lacustris is included. However, presently our data suggest that the common outgroup to all Baikalian species is the nearest sister species G. duebeni. This result corroborates the recent study by Hou and Sket (2016) [32].

The phylogenetic tree demonstrates separation of Baikalian amphipod species into two clades where the

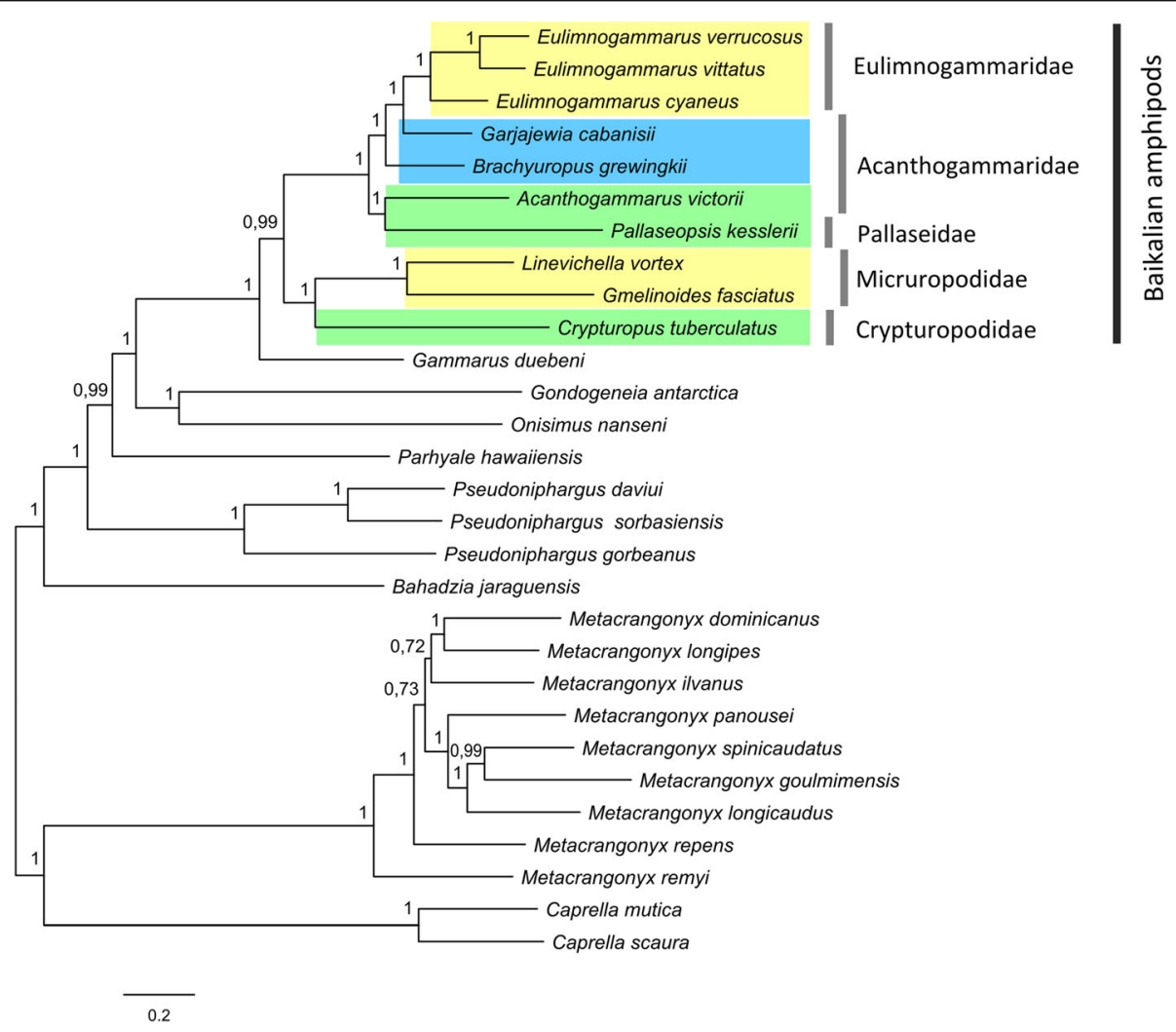

Fig. 3 Phylogenetic inference (BI) of amphipods based on 13 mitochondrial protein-coding genes sequences. Numbers above the branches indicate Bayesian posterior probabilities. Coloured rectangles denote depths of habitats of Baikalian amphipods. Yellow rectangles denote littoral species, green ones denote sub-littoral species, blue ones denote abyssal species 
one includes species from the Micruropodidae and Crypturopodidae families and the other includes species from the Acanthogammaridae, Pallaseidae, and Eulimnogammaridae families (Fig. 3). This clusterization is in concordance with the current view on the existence of two major amphipod lineages in Lake Baikal, which is based on morphological investigations [25] and molecular phylogenetic data [30-32, 35].

The phylogenetic tree obtained in our study can be used to make some assumptions about the origination of certain ecological features of Baikalian amphipods. The Baikalian amphipods C. tuberculatus, $L$. vortex and G. fasciatus, which comprise one of the lineages in our study (Fig. 3), are mainly shallow-water inhabitants, having smooth body and display tolerance to warm water $[13,14,115,116]$. Ancestors of these species may have originated during the Tertiary period when the climate was warm [117] and therefore they may be warm-water relicts $[14,25]$. The second lineage of Baikalian amphipods contains species that possess more diverse morphological features, lifestyle and ecological niches. The radiation of this lineage presumably coincided with the completion of climate cooling period in the late Eocene - early Oligocene according to Kamaltynov [14]. This lineage is subdivided into two clades: the first one includes armored and relatively shallow water species $P$. kesslerii (Pallaseidae) and $A$. victorii (Acanthogammaridae) [13, 14], the second clade consists of two armored deep-water predator species ( $G$. cabanisii and B. grewingkii) and a derived clade of smooth littoral amphipods of Gen. Eulimnogammarus Bazikalova, 1945, which differ from the rest by their feeding habits. The separation of species from the second lineage into two clades is also supported by morphological features, as A.victorii and P.kesslerii possess more plesiomorphic traits in comparison to the rest of the species $[13,14]$. The topology of the BI tree shows that the species of Eulimnogammarus genus may have originated from an ancestor inhabiting the abyssal zone of Lake Baikal. However, it is possible that an expanded sampling of Baikalian species may yet show the different trends of origination of the extant amphipods inhabiting different depths of the lake.

The topology of the BI tree revealed the paraphyly of family Acanthogammaridae, which in our study includes A.victorii, B.grewingkii and G.cabanisii. The phylogenetic separation of species within the Acanthogammaridae family (according to the contemporary taxonomy) was also observed in previous studies, though the trees in those studies were poorly resolved [28, 30, 35]. The Acanthogammaridae includes species with diverse morphological and ecological features united on the basis of armament characteristics [14]. However, according to Kamaltynov, the taxonomy of contemporary Acanthogammaridae still needs refinement. Some genera have features that may be sufficient for establishing new families. Additional molecular phylogenetic data including some nuclear markers and larger sampling of species from the Acanthogammaridae is necessary for the description of new families.

\section{Conclusion}

The detailed comparative study of mitochondrial genomes of endemic Baikalian amphipods belonging to the most diverse species flock of Lake Baikal is reported. The newly sequenced complete and nearly complete mitochondrial genomes of seven Baikalian species were presented in this study i.e. Acanthogammarus victorii, Crypturopus tuberculatus, Eulimnogammarus cyaneus, Garjajewia cabanisii, Gmelinoides fasciatus, Linevichella vortex and Pallaseopsis kesslerii.

The examined mitochondrial genome sequences were used to resolve phylogenetic relationships within the group of Baikalian amphipods. The branching order of the phylogenetic tree supports the separation of Baikalian species into two major lineages. Our data also support the paraphyly of Acanthogammaridae. The measurement of nucleotide diversity of protein-coding parts of Baikalian and non-Baikalian species allowed us to define the fragments of mitogenome most suitable for different scales of phylogenetic and/or population studies of amphipods.

The structural analysis of available Baikalian amphipod mitochondrial genomes revealed high variability in their length and gene order. Gene order of all mitochondrial genomes studied is changed relative to the pancrustacean ground pattern. Four species (G.cabanisii, E.vittatus, A.victorii and G.fasciatus) have extra tRNA genes copies. More severe rearrangements of protein coding genes and ribosomal RNA genes are found in P. kesslerii, C. tuberculatus and G. fasciatus. Multiple and unusually long intergenic spacers are found in mitochondrial genomes of B.grewingkii, P.kesslerii and G.fasciatus. Unusually high structural diversity of the amphipod mitochondrial genomes in Lake Baikal points at the possibility of high mutagenic pressure. This turns Baikalian amphipods into a potentially attractive model for studies of mitochondrial genome evolution in general.

\section{Methods}

\section{Sampling, DNA extraction, mitochondrial genome amplification, sequencing}

Amphipods species used for this study were collected in Lake Baikal from 2011 to 2013. Sampling was performed both manually at the water edge and by trawling from the ship at greater depths (Table 1). The species investigated in the current study were selected to maximally cover the range of species morphologies and ecological niches such as depth inhabited. Additional requirement was the ease of species diagnosis of the specimens. 
Total DNA was extracted using modified CTAB method [118]. Depending on size of species we used either a whole animal or its part (a leg) for DNA extraction. The species identification was carried out using taxonomic system of Kamaltynov [17].

Total DNA samples of three out of seven amphipod species (G. fasciatus, A. victorii and G. cabanisii) was used directly for Illumina next generation sequencing libraries preparation. Paired-end libraries with insert size of 300 b.p. and 600 b.p. were prepared according to protocols provided by manufacturer for HiSeq (TruSeq DNA Sample Prep Kit) and MiSeq (Nextera DNA Library Preparation Kit) Systems (Illumina, San Diego, CA, USA).

Alternatively, DNA samples of other four species ( $P$. kesslerii, $L$. vortex, C. tuberculatus and E. cyaneus) were used for long-range amplification of mitochondrial DNA. Mitochondrial genomes sequences were amplified as two fragments overlapping between $\operatorname{cox} 1$ to $r r n L$ genes (Additional file 9). Primers were designed based on the alignment of cox1 and rrnL gene sequences of Baikalian amphipods available in GenBank. Additionally the universal Folmer's primers were used [119]. The sequences of primers used in this study are available in Additional file 5.

Primers COI_L1 and 16S_H were used to amplify the c.a. $11 \mathrm{~Kb}$ long (in all species) fragment spanning from cox1 to rrnL. PCR was performed using EncycloPlus PCR kit (Eurogen, Moscow, Russia). Each reaction contained $1 \mu \mathrm{l}$ of $10 \times$ Encyclo buffer, $0.2 \mu \mathrm{l}$ of dNTP Mixture (10 mM each), $0.5 \mu \mathrm{l}$ of each primer, $1 \mu \mathrm{l}$ of template DNA (10-50 ng), $0.2 \mu \mathrm{l}$ of Encyclo polymerase mix and $6.6 \mu \mathrm{l}$ of sterile water up to $10 \mu \mathrm{l}$. Amplification was carried out under following conditions: $95{ }^{\circ} \mathrm{C}$ for $1 \mathrm{~min}$., followed by 30 cycles of $93^{\circ} \mathrm{C}$ for $15 \mathrm{~s}$., $60^{\circ} \mathrm{C}$ for 15 s., $72{ }^{\circ} \mathrm{C}$ for 9 min., with final elongation at $72{ }^{\circ} \mathrm{C}$ for $3 \mathrm{~min}$. Different pairs of primers were used to amplify the second fragment spanning from $r r n L$ to $\operatorname{cox} 1$ in cases of different species as summarized in Additional file 5. PCR conditions were the same but the elongation times were decreased.

PCR products were purified by ethanol precipitation and were further utilized for libraries preparation using the Nextera DNA Library Preparation Kit (Illumina, San Diego, CA, USA) provided by manufacturer. The pairedend libraries with insert length of 600 b.p. were constructed and sequenced using MiSeq System (Illumina, San Diego, CA, USA).

\section{Reads processing, mitochondrial genomes assembly and annotation}

All sets of reads were cleaned from adapters, and parts with a quality score below 15 were trimmed using Trimmomatic-0.32 [120]. De-novo assembly was carried out with SPAdes 3.0.0 assembler [121]. Scaffolds of mitochondrial genome in the assemblies were identified using BLAST [122] and the reference sequences of amphipod E. verrucosus. Complete and nearly complete amphipod mitochondrial genome sequences obtained after assemblies were further used as reference sequences for mapping reads of appropriate species using Bowtie2 2.1.0 [123]. All generated read alignment files were used for manual correction of errors in reference sequences and for estimation of coverage depth. Visualization of read alignment files was made by Tablet 1.13.07.31 [124].

An automatic annotation of mitochondrial genome sequences was performed using the MITOS pipeline with default settings [125]. GenomeView browser [126] was used for visualization of annotation files and manual correction of gene boundaries. PCGs boundaries were verified by comparison with the orthologs of other amphipods and also taking into account adjacent tRNA genes positions [61]. rRNA genes boundaries were identified by comparison to mitochondrial rRNA genes sequences of other amphipods. tRNA genes and their secondary structures were predicted by MiTfi [127] as part of the MITOS pipeline [125].

\section{Protein-coding genes analyses}

Nucleotide composition and codon usage were calculated by The Sequence Manipulation Suite [128]. Effective number of codons was assessed using INCA 2.1 [129]. AT and GC skew of entire mitochondrial sequences were calculated using the following formulae: AT-skew $=(\mathrm{A}-\mathrm{T}) /(\mathrm{A}+\mathrm{T})$ and $\mathrm{GC}$-skew $=(\mathrm{G}-\mathrm{C}) /(\mathrm{G}+\mathrm{C})$ [130]. Visualization of AT-skew and GC-skew plots as well as AT content plot for $(+)$ strand were made by a custom Python script with a sliding window of 100 b.p. with steps of 10 b.p. Nucleotide diversity (Pi) was estimated for every protein-coding gene of Baikalian and non-Baikalian amphipods (see the list of species in Additional file 5) using DNAsp v.5 [131].

\section{Phylogenetic inference}

Protein coding nucleotide sequences were used for the phylogenetic inferences. Non-Baikalian amphipods were represented in the dataset by a single sequence for each species available in GeneBank by March 2016 (Additional file 5).

Each protein coding gene sequence set was aligned separately in codon-based fashion with TranslatorX web server [132] using ClustalW algorithm and then the sets were concatenated using Seaview 4.5.4 [133]. A resultant alignment contained 11,013 characters.

The best model of nucleotide substitution (GTR + I + G) was chosen with jModelTest [134]. The phylogenetic trees were built by MrBayes v. 3.2.1. [135]. Four independent runs of four MCMC chains were performed. Chains were run for five million generations, the first 30\% 
of generations were discarded as burn-in. The resultant phylogenetic tree was visualized in FigTree v.1.4.2. [136]. Metacrangonictidae clade was used as a root of the tree.

\section{Additional files}

Additional file 1: AT content plots for the (+) strand of mitochondrial genomes of Baikalian amphipods under study. The beginning of every graph corresponds to the start of the cox 1 gene. Dashed lines indicate the places of disruptions in incompletely sequenced mitochondrial genomes. The putative CRs are marked by the colored boxes. (PDF 16,893 kb)

Additional file 2: AT-skew and GC-skew plots for the ( + ) strand of mitochondrial genomes of Baikalian amphipods under study. The beginning of every graph corresponds to the start of the cox 1 gene. Dashed lines indicate the places of disruptions in incompletely sequenced mitochondrial genomes. (PDF 18,605 kb)

Additional file 3: Organization of the mitochondrial genomes of Baikalian amphipods under study. The incomplete stop codons are labeled in the tables with parentheses. (XLSX $28 \mathrm{~kb}$ )

Additional file 4: Summary of codon usage in protein coding genes of mitochondrial genomes of studied Baikalian amphipods. Bold notations indicate species with incomplete protein coding sequences. Sign "\#" indicates total number of certain codon in protein-coding sequences of every species; " $\%$ " indicates percent of certain codon in total coding sequence in every species. (XLSX $17 \mathrm{~kb}$ )

Additional file 5: Table S1. Primers used for amplification of Baikalian amphipod mitochondrial genomes. Table S2. Accession numbers of amphipod mitochondrial genomes from GenBank database used in the study (XLSX $11 \mathrm{~kb})$

Additional file 6: The predicted mitochondrial tRNAs secondary structures of Baikalian amphipods under study. (PDF $9263 \mathrm{~kb}$ )

Additional file 7: Nucleotide composition statistics for ribosomal RNA genes in mitochondrial genomes of studied Baikalian amphipods. Bold numbers indicate incomplete sequences. (XLSX $10 \mathrm{~kb}$ )

Additional file 8: Alignment of the putative CR sequence of Garjajewia cabanisii mitochondrial genome with its incompletely sequenced counterpart. Dashed lines indicate a missing sequence. (PNG $370 \mathrm{~kb}$ )

Additional file 9: The scheme of regions amplified by PCR in mitochondrial genomes of Baikalian amphipods. Eulimnogammarus verrucosus was used as an example of Baikalian amphipod. Proteincoding genes and ribosomal RNA genes are shown as sectors. Transfer RNA genes are labeled by their single-letter amino acid code. The features located on the (-) strand are shown inside the circle. The semicircles outside of the gene map denote the regions of the long-range amplification. (PNG $1167 \mathrm{~kb}$ )

\section{Abbreviations}

Bl: Bayesian inference; CR: Control region; ENC: Effective number of codons; PCGs: Protein-coding genes

\section{Acknowledgments}

Computational experiments have been performed with HPC cluster "Academician V.M. Matrosov" (Irkutsk Supercomputer Centre of SB RAS, http://hpc.icc.ru). We are grateful to the three anonymous reviewers for their valuable comments and suggestion that helped us to improve the manuscript.

\section{Declarations}

This article has been published as part of BMC Genetics Vol 17 Suppl 14, 2016 Selected articles from BGRSISB-2016: genomics. The full contents of the supplement are available online at http://bmcgenomics.biomedcentral.com/ articles/supplements/volume-17-supplement-14.

\section{Funding}

The work was supported by the governmentally funded project No 03452014-0005; Russian Foundation for Basic Research (Grants no. 15-04-05841, 15-07-03827 and 15-04-03848). Phylogenetic analysis in this study was supported by the Russian Science Foundation (Grant Number: 14-50-00029). The publication cost of this article has been funded by the Russian Foundation for Basic Research.

\section{Availability of data and materials}

All data generated or analysed during this study are included in this published article and its supplementary information files.

\section{Authors' contributions}

EVR and DYS are responsible for conception and design of the study. EVR, DYS and EAS carried out taxonomic sampling. RMK performed the morphological identification of species. EVR performed the laboratory works. MDL performed the library preparation for Illumina Sequencing. KVM and EVR are responsible for assembly and annotation of mitochondrial genomes. DYS, WA, RMK, EAS, AVG and ASA participated in statistical and phylogenetic analyses. EVR wrote the manuscript. All authors read and approved the final version of the manuscript.

\section{Competing interests}

The authors declared that they have no competing interests.

\section{Consent for publication}

Not applicable.

\section{Ethics approval and consent to participate}

Not applicable.

\section{Author details}

'Laboratory of Molecular Systematics, Limnological Institute, Siberian Branch of Russian Academy of Sciences, Irkutsk 664033, Russian Federation. ${ }^{2}$ Belozersky Institute for Physicochemical Biology, Lomonosov Moscow State University, Moscow 119991, Russian Federation. Institute for Information Transmission Problems, Russian Academy of Sciences, Moscow 127994, Russian Federation. ${ }^{4}$ Extreme Biology Laboratory, Institute of Fundamental Medicine and Biology, Kazan Federal University, Kazan 420012, Russian Federation. ${ }^{5}$ Institute for System Dynamics and Control Theory, Siberian Branch of Russian Academy of Sciences, Irkutsk 664033, Russian Federation. ${ }^{6}$ Faculty of Biology and Soil Studies, Irkutsk State University, Irkutsk 664003, Russian Federation.

Published: 28 December 2016

\section{References}

1. Cristescu ME, Adamowicz SJ, Vaillant JJ, Haffner DG. Ancient lakes revisited: from the ecology to the genetics of speciation. Mol Ecol. 2010;19(22):4837-51.

2. Martens K. Speciation in ancient lakes. Trends Ecol Evol. 1997:12:177-82.

3. Schön I, Martens K. Adaptive, pre-adaptive and non-adaptive components of radiations in ancient lakes: a review. Org Divers Evol. 2004;4(3):137-56.

4. Kozhov MM. Biology of Lake Baikal. Moscow: AN SSSR Publication; 1963.

5. Kozhova OM, Izmest'eva LR, Baikal L. Evolution and Biodiversity. Leiden: Backhuys; 1998.

6. Mats VD, Khlystov OM, De Batist M, Ceramicola S, Lomonosova TK, Klimansky A. Evolution of the Academician Ridge Accommodation Zone in the central part of the Baikal Rift, from high-resolution reflection seismic profiling and geological field investigations. Int J Earth Sci. 2000;89(2):229-50

7. Brooks JL. Speciation in ancient lakes. Quart Rev Biol. 1950;25(1):30-60,

8. Mats VD. The structure and development of the Baikal rift depression. Earth Sci Rev. 1993;34(2):81-118

9. Väinölä R, Kamaltynov RM. Species diversity and speciation in the endemic amphipods of Lake Baikal: molecular evidence. Crustaceana. 1999;72(8):945-56.

10. Mashiko K, Kamaltynov R, Morino H, Sherbakov DY. Genetic differentiation among gammarid (Eulimnogammarus cyaneus) populations in Lake Baikal, East Siberia. Arch Hydrobiol. 2000;148(2):249-61.

11. Daneliya ME, Kamaltynov RM, Väinölä R. Phylogeography and systematics of Acanthogammarus s.str., giant amphipod crustaceans from Lake Baikal. Zool Scr. 2011;40(6):623-37.

12. Bedulina DS, Takhteev W, Pogrebnyak SG, Govorukhina EB, Madyarova EV, Lubyaga YA, et al. On Eulimnogammarus messerschmidtii, sp. n. (Amphipoda: Gammaridea) from Lake Baikal, Siberia, with redescription of E. cyanoides (Sowinsky) and remarks on taxonomy of the genus Eulimnogammarus. Zootaxa. 2014;3838(5):518-44.

13. Bazikalova AY. Lake Baikal amphipods. Proceedings of the Baikal Limnological Station. Moscow: Acad.Sci.Publishing House; 1945. p. 1-440. 
14. Kamaltynov RM. Amphipoda: Gammaroidea. In: Timoshkin OA, editor. Index of animal species inhabiting Lake Baikal and its catchment area. In 2 volumes. Vol. 1. Novosibirsk: Nauka; 2001. p. 572-832.

15. Bazikalova AY. Bottom-living fauna. In: Galaziy Gl, editor. Proceedings of Limnological Institute. Leningrad: Publishing House Nauka; 1971. p. 95-114.

16. Takhteev W, Mekhanikova IV. New species of the sideswimmers (Crustacea, Amphipoda) from the mountain streams of Khamar-Daban ridge. Researches of the water ecosystems of East Siberia Biodiversity of the Baikal Region. Irkutsk: Proceedings of the Biology and Soil Department of the Irkutsk State University Press; 2000

17. Kamaltynov RM. Amfipoda: Gammaroidea in Angara and Yenisei rivers. In: Timoshkin OA, Proviz VI, Sitnikova TY, Slugina ZV, Melnik NG, editors. Index of animal species inhabiting Lake Baikal and its catchment area. In 2 volumes. Vol. 2: Basins and channels in the south of East Siberia and North Mongolia. Novosibirsk: Nauka; 2009. p. 297-329.

18. Mekhanikova IV, Chapelle G, De Broyer C. Echiuropus bekmanae n. sp. (Crustacea, Amphipoda, Carinagammaridae) from Lake Baikal, retrieved by a new deep-water sampling device. Hydrobiologia. 2001;462(1-2):241-51.

19. Tachteev W. Addition to revision of the genus Poekilogammarus (Crustacea, Amphipoda, Gammaridea) from Lake Baikal. Russian Journal of Zoology. 2000;79(6):649-61.

20. Barnard JL, Barnard CM. Freshwater Amphipoda of the world. Vernon: Hayfield Associates; 1983.

21. Bousfield EL. A new look at the systematics of gammaroidean amphipods of the world. Crustaceana. 1977;Suppl 4:282-316

22. Bousfield EL. Amphipoda. In: Parker SP, editor. Synopsis and classification of living organisms. New York: McGraw-Hill; 1982. p. 254-94.

23. Daneliya ME, Kamaltynov RM, Kontula T, Väinölä R. Systematics of the Baikalian Babr (Crustacea: Amphipoda: Pallaseidae). Zootaxa. 2009;2276:49-68.

24. Kamaltynov RM. On the present state of amphipod systematics. Hydrobiol J. 1993;26(6):82-92

25. Kamaltynov RM. On the evolution of Lake Baikal amphipods. Crustaceana. 1999;72(8):921-31.

26. Kamaltynov RM. On the higher classification of Lake Baikal amphipods. Crustaceana. 1999;72(8):933-44

27. Takhteev W. Essays on the amphipods of Lake Baikal (systematics, comparative ecology, evolution). Irkutsk: Irkutsk State University Press; 2000.

28. Sherbakov DY, Kamaltynov RM, Ogarkov OB, Väinölä R, Vainio JK, Verheyen E. On the Phylogeny of Lake Baikal Amphipods in the Light of Mitochondrial and Nuclear Dna Sequence Data. Crustaceana. 1999:72(8):911-9.

29. Sherbakov DY. Molecular phylogenetic studies on the origin of biodiversity in Lake Baikal. Trends Ecol Evol. 1999;14(3):92-5.

30. MacDonald III KS, Yampolsky L, Duffy JE. Molecular and morphological evolution of the amphipod radiation of Lake Baikal. Mol Phylogenet Evol. 2005;35(2):323-43.

31. Hou Z, Sket B, Li S. Phylogenetic analyses of Gammaridae crustacean reveal different diversification patterns among sister lineages in the Tethyan region. Cladistics. 2014;30(4):352-65.

32. Hou Z, Sket B. A review of Gammaridae (Crustacea: Amphipoda): the family extent, its evolutionary history, and taxonomic redefinition of genera. Zool J Linn Soc. 2016:176(2):323-48.

33. Englisch U, Coleman CO, Wägele JW. First observations on the phylogeny of the families Gammaridae, Crangonyctidae, Melitidae, Niphargidae, Megaluropidae and Oedicerotidae (Amphipoda, Crustacea), using small subunit rDNA gene sequences. J Nat Hist. 2003:37(20):2461-86.

34. Väinölä R, Witt JDS, Grabowski M, Bradbury JH, Jazdzewski K, Sket B. Global diversity of amphipods (Amphipoda; Crustacea) in freshwater. Hydrobiologia. 2008;595(1):241-55.

35. Sherbakov DY, Kamaltynov RM, Ogarkov OB, Verheyen E. Patterns of evolutionary change in Baikalian gammarids inferred from DNA sequences (Crustacea, Amphipoda). Mol Phylogenet Evol. 1998;10(2):160-7.

36. Ogarkov OB, Kamaltynov RM, Belikov SI, Sherbakov DY. Phylogenetic relatedness of the Baikal Lake endemical [sic.] amphipods (Crustacea, Amphipoda) deduced from partial nucleotide sequences of the cytochrome oxidase subunit III genes. Mol Biol. 1997;31:24-9.

37. Hou Z, Fu J, Li S. A molecular phylogeny of the genus Gammarus (Crustacea: Amphipoda) based on mitochondrial and nuclear gene sequences. Mol Phylogenet Evol. 2007;45(2):596-611.

38. Hou Z, Sket B, Fišer C, Li S. Eocene habitat shift from saline to freshwate promoted Tethyan amphipod diversification. Proc Natl Acad Sci U S A. 2011;108(35):14533-8.
39. Bauza-Ribot MM, Jaume D, Juan C, Pons J. The complete mitochondrial genome of the subterranean crustacean Metacrangonyx longipes (Amphipoda): a unique gene order and extremely short control region. Mitochondrial DNA. 2009:20(4):88-99.

40. Bauza-Ribot MM, Juan C, Nardi F, Oromí P, Pons J, Jaume D. Mitogenomic phylogenetic analysis supports continental-scale vicariance in subterranean thalassoid crustaceans. Curr Biol. 2012;22(21):2069-74.

41. Ito A, Aoki MN, Yokobori S, Wada H. The complete mitochondrial genome of Caprella scaura (Crustacea, Amphipoda, Caprellidea), with emphasis on the unique gene order pattern and duplicated control region. Mitochondrial DNA. 2010;21(5):183-90.

42. Ki JS, Hop H, Kim SJ, Kim IC, Park HG, Lee JS. Complete mitochondrial genome sequence of the Arctic gammarid, Onisimus nanseni (Crustacea; Amphipoda): Novel gene structures and unusual control region features. Comp Biochem Physiol Part D Genomics Proteomics. 2010;5(2):105-15.

43. Kilpert F, Podsiadlowski $L$. The mitochondrial genome of the Japanese skeleton shrimp Caprella mutica (Amphipoda: Caprellidea) reveals a unique gene order and shared apomorphic translocations with Gammaridea. Mitochondrial DNA. 2010:21(3-4):77-86.

44. Krebes L, Bastrop R. The mitogenome of Gammarus duebeni (Crustacea Amphipoda): A new gene order and non-neutral sequence evolution of tandem repeats in the control region. Comp Biochem Physiol Part D: Genomics Proteomics. 2012;7(2):201-11.

45. Pons J, Bauzà-Ribot MM, Jaume D, Juan C. Next- generation sequencing, phylogenetic signal and comparative mitogenomic analyses in Metacrangonyctidae (Amphipoda: Crustacea). BMC Genomics. 2014 doi:10.1186/1471-2164-15-566.

46. Shin SC, Cho J, Lee JK, Ahn do H, Lee H, Park H. Complete mitochondrial genome of the Antarctic amphipod Gondogeneia antarctica (Crustacea, amphipod). Mitochondrial DNA. 2012;23(1):25-7.

47. Stokkan M, Jurado-Rivera JA, Juan C, Jaume D, Pons J. Mitochondrial genome rearrangements at low taxonomic levels: three distinct mitogenome gene orders in the genus Pseudoniphargus (Crustacea: Amphipoda). Mitochondrial DNA. 2016:27(5):3579-89.

48. Francino MP, Ochman H. Strand asymmetries in DNA evolution. Trends Genet. 1997:13:240-5.

49. Hassanin A, Leger N, Deutsch J. Evidence for multiple reversals of asymmetric mutational constraints during the evolution of the mitochondrial genome of Metazoa, and consequences for phylogenetic inferences. Syst Biol. 2005;54(2):277-98.

50. Kilpert F, Podsiadlowski L. The complete mitochondrial genome of the common sea slater, Ligia oceanica (Crustacea, Isopoda) bears a novel gene order and unusual control region features. BMC Genomics. 2006. doi: 10 1186/1471-2164-7-241

51. Krapp T, Lang C, Libertini A, Melzer RR. Caprella scaura Templeton, 1836 sensu lato (Amphipoda: Caprellidae) in the Mediterranean. Org Divers Evol. 2006:6(2):77-81.

52. Boos K, Ashton GV, Cook EJ. The Japanese skeleton shrimp Caprella mutica (Crustacea, Amphipoda): a global invader of coastal waters. In: Galil BS, Clark PF, Carlton JT, editors. In the Wrong Place-Alien Marine Crustaceans: Distribution, Biology and Impacts. Netherlands: Springer; 2011. p. 129-56.

53. World Register of Marine Species. 2016. http://www.marinespecies.org at VLIZ. Accessed 10 Sept 2016.

54. Jaumel D, Wagner HP. New cave-dwelling amphipods (Lysianassidae, Hadziidae) from the Dominican Republic (Hispaniola). Contrib Zool. 1998;68(1):37-66.

55. Miloslavich P, Díaz JM, Klein E, Alvarado JJ, Díaz C, Gobin J, et al. Marine biodiversity in the Caribbean: regional estimates and distribution patterns. PLoS One. 2010. doi:10.1371/journal.pone.0011916.

56. Gaston KJ, Spicer Jl. The relationship between range size and niche breadth: a test of using five species of Gammarus (Amphipoda). Glob Ecol Biogeogr. 2001:10(2):179-88

57. De Broyer C, Lowry JK, Jazdzewski K, Robert H. Catalogue of the Gammaridean and Corophiidean Amphipoda (Crustacea) of the Southern Ocean, with distribution and ecological data. In: De Broyer C, editor. Census of Antarctic Marine Life: Synopsis of the Amphipoda of the Southern Ocean. Vol. 1. Brussels: Edition of Royal Belgian Institute of Natural Sciences; 2007. p. 1-325.

58. Wei SJ, Shi M, Chen XX, Sharkey MJ, van Achterberg C, Ye GY, et al. New views on strand asymmetry in insect mitochondrial genomes. PLoS One. 2010. doi:10.1371/journal.pone.0012708. 
59. Hassanin A. Phylogeny of Arthropoda inferred from mitochondrial sequences: Strategies for limiting the misleading effects of multiple changes in pattern and rates of substitution. Mol Phylogenet Evol. 2006;38(1):100-16.

60. Boore JL, Macey JR, Medina M. Sequencing and comparing whole mitochondrial genomes of animals. Meth Enzymol. 2005;395:311-48.

61. Ojala D, Montoya J, Attardi G. tRNA punctuation model of RNA processing in human mitochondria. Nature. 1981;290:470-4.

62. Wilson K, Cahill V, Ballment E, Benzie J. The complete sequence of the mitochondrial genome of the crustacean Penaeus monodon: are malacostracan crustaceans more closely related to insects than to branchiopods? Mol Biol Evol. 2000;17(6):863-74.

63. Wright $F$. The 'effective number of codons' used in a gene. Gene. 1990;87(1):23-9.

64. Lloyd RE, Foster PG, Guille M, Littlewood DT. Next generation sequencing and comparative analyses of Xenopus mitogenomes. BMC Genomics. 2012. doi:10.1186/1471-2164-13-496.

65. Mohandas N, Pozio E, La Rosa G, Korhonen PK, Young ND, Koehler AV, et al. Mitochondrial genomes of Trichinella species and genotypes - a basis for diagnosis, and systematic and epidemiological explorations. Int J Parasitol. 2014;44(14):1073-80

66. Oliveira DC, Raychoudhury R, Lavrov DV, Werren JH. Rapidly evolving mitochondrial genome and directional selection in mitochondrial genes in the parasitic wasp Nasonia (Hymenoptera: Pteromalidae). Mol Biol Evol. 2008;25(10):2167-80.

67. Xiao JH, Jia JG, Murphy RW, Huang DW. Rapid evolution of the mitochondrial genome in Chalcidoid wasps (Hymenoptera: Chalcidoidea) driven by parasitic lifestyles. PLoS One. 2011. doi:10.1371/journal.pone.0026645.

68. Zhao L, Zhang X, Tao X, Wang W, Li M. Preliminary analysis of the mitochondrial genome evolutionary pattern in primates. Dongwuxue Yanjiu. 2012;33(3-4):47-56.

69. Xie Y, Niu L, Zhao B, Wang Q, Nong X, Chen L, et al. Complete mitochondrial genomes of chimpanzee- and gibbon-derived Ascaris isolated from a zoological garden in southwest China. PLoS One. 2013. doi:10.1371/journal.pone.0082795.

70. Ye F, Liu T, King SD, You P. Mitochondrial genomes of two phlebotomine sand flies, Phlebotomus chinensis and Phlebotomus papatasi (Diptera: Nematocera), the first representatives from the family Psychodidae. Parasit Vectors. 2015. doi:10.1186/s13071-015-1081-1.

71. Rivarola-Duarte L, Otto C, Juhling F, Schreiber S, Bedulina D, Jakob L, et al. A first glimpse at the genome of the Baikalian amphipod Eulimnogammarus verrucosus. J Exp Zool B Mol Dev Evol. 2014;322:177-89.

72. Lin FJ, Liu Y, Sha Z, Tsang LM, Chu KH, Chan TY, Liu R, Cui Z. Evolution and phylogeny of the mud shrimps (Crustacea: Decapoda) revealed from complete mitochondrial genomes. BMC Genomics. 2012. doi:10.1186/1471-2164-13-631.

73. Liu Y, Cui Z. Complete mitochondrial genome of the Chinese spiny lobster Panulirus stimpsoni (Crustacea: Decapoda): genome characterization and phylogenetic considerations. Mol Biol Rep. 2011;38(1):403-10.

74. Shi H, Liu R, Sha Z, Ma J. Complete mitochondrial DNA sequence of Stenopus hispidus (Crustacea: Decapoda: Stenopodidea) and a novel tRNA gene cluster. Mar Genomics. 2012;6:7-15.

75. Masta SE. Mitochondrial sequence evolution in spiders: intraspecific variation in tRNAs lacking the T\%C arm. Mol Biol Evol. 2000;17(7):1091-100

76. Campbell NJ, Barker SC. An unprecedented major rearrangement in an arthropod mitochondrial genome. Mol Biol Evol. 1998;15:1786-87.

77. Yamazaki N, Ueshima R, Terrett JA, Yokobori SI, Kaifu M, Segawa R, et al. Evolution of pulmonate gastropod mitochondrial genomes: comparisons of gene organizations of Euhadra, Cepaea and Albinaria and implications of unusual tRNA secondary structures. Genetics. 1997;145(3):749-58.

78. Okimoto R, Wolstenholme DR. A set of tRNAs that lack either the T psi C arm or the dihydrouridine arm: towards a minimal tRNA adaptor. EMBO J. 1990;9(10):3405-11.

79. Macey JR, Larson A, Ananjeva NB, Papenfuss TJ. Replication slippage may cause parallel evolution in the secondary structures of mitochondrial transfer RNAs. Mol Biol Evol. 1997;14(1):30-9.

80. Junqueira $A C$, Lessinger $A C$, Torres $T$, da Silva FR, Vettore AL, Arruda P, et al. The mitochondrial genome of the blowfly Chrysomya chloropyga (Diptera: Calliphoridae). Gene. 2004;339:7-15.

81. Kocher A, Kamilari M, Lhuillier E, Coissac E, Péneau J, Chave J, Murienne J. Shotgun assembly of the assassin bug Brontostoma colossus mitochondrial genome (Heteroptera, Reduviidae). Gene. 2014;552(1):184-94.

82. Kim I, Lee EM, Seol KY, Yun EY, Lee YB, Hwang JS, Jin BR. The mitochondrial genome of the Korean hairstreak, Coreana raphaelis (Lepidoptera: Lycaenidae). Insect Mol Biol. 2006;15(2):217-25.
83. Sun S, Kong L, Yu H, Li Q. The complete mitochondrial DNA of Tegillarca granosa and comparative mitogenomic analyses of three Arcidae species. Gene. 2015;557(1):61-70.

84. Kumazawa $Y$, Nishida M. Sequence evolution of mitochondrial tRNA genes and deep-branch animal phylogenetics. J Mol Evol. 1993;37(4):380-98.

85. Kakehashi R, Kurabayashi A, Oumi S, Katsuren S, Hoso M, Sumida M. Mitochondrial genomes of Japanese Babina frogs (Ranidae, Anura): unique gene arrangements and the phylogenetic position of genus Babina. Genes Genet Syst. 2013;88(1):59-67.

86. Liu C, Chang J, Ma C, Li L, Zhou S. Mitochondrial genomes of two Sinochlora species (Orthoptera): novel genome rearrangements and recognition sequence of replication origin. BMC Genomics. 2013. doi:10.1186/1471-2164-14-114.

87. Cantatore P, Gadaleta MN, Roberti M, Saccone C, Wilson AC. Duplication and remoulding of tRNA genes during the evolutionary rearrangement of mitochondrial genomes. Nature. 1987;329:853-55.

88. Belinky F, Rot C, llan M, Huchon D. The complete mitochondrial genome of the demosponge Negombata magnifica (Poecilosclerida). Mol Phylogenet Evol. 2008;47(3):1238-43.

89. Lavrov DV, Lang BF. Transfer RNA gene recruitment in mitochondrial DNA. Trends Genet. 2005:21(3):129-33.

90. Wang X, Lavrov DV. Gene recruitment - a common mechanism in the evolution of transfer RNA gene families. Gene. 2011;475(1):22-9.

91. Sahyoun AH, Hölzer M, Jühling F, Höner zu Siederdissen C, Al-Arab M, Tout $\mathrm{K}$, et al. Towards a comprehensive picture of alloacceptor tRNA remolding in metazoan mitochondrial genomes. Nucleic Acids Res. 2015;43(16):8044-56.

92. Rawlings TA, Collins TM, Bieler R. Changing identities: tRNA duplication and remolding within animal mitochondrial genomes. Proc Natl Acad Sci U S A. 2003;100(26):15700-5.

93. Rawlings TA, Maclnnis MJ, Bieler R, Boore JL, Collins TM. Sessile snails, dynamic genomes: gene rearrangements within the mitochondrial genome of a family of caenogastropod molluscs. BMC Genomics. 2010. doi:10.1186/ 1471-2164-11-440.

94. Iannelli F, Griggio F, Pesole G, Gissi C. The mitochondrial genome of Phallusia mammillata and Phallusia fumigata (Tunicata, Ascidiacea): high genome plasticity at intra-genus level. BMC Evol Biol. 2007. doi:10.1186/1471-2148-7-155.

95. Kumazawa Y, Miura S, Yamada C, Hashiguchi Y. Gene rearrangements in gekkonid mitochondrial genomes with shuffling, loss, and reassignment of tRNA genes. BMC Genomics. 2014. doi:10.1186/1471-2164-15-930.

96. Macey JR, Larson A, Ananjeva NB, Fang Z, Papenfuss TJ. Two novel gene orders and the role of light-strand replication in rearrangement of the vertebrate mitochondrial genome. Mol Biol Evol. 1997;14(1):91-104.

97. Matsumoto Y, Yanase T, Tsuda T, Noda H. Species-specific mitochondrial gene rearrangements in biting midges and vector species identification. Med Vet Entomol. 2009;23(1):47-55.

98. Rawlings TA, Collins TM, Bieler R. A major mitochondrial gene rearrangement among closely related species. Mol Biol Evol. 2001;18(8):1604-9.

99. Saito S, Tamura K, Aotsuka T. Replication origin of mitochondrial DNA in insects. Genetics. 2005;171(4):1695-705.

100. Cook CE. The complete mitochondrial genome of thestomatopod crustacean Squilla mantis. BMC Genomics. 2005. doi:10.1186/1471-2164-6-105.

101. Doublet V, Helleu Q, Raimond R, Souty-Grosset C, Marcade I. Inverted repeats and genome architecture conversions of terrestrial isopods mitochondrial DNA. J Mol Evol. 2013;77(3):107-18.

102. Shao R, Barker SC. The highly rearranged mitochondrial genome of the plague thrips, Thrips imaginis (Insecta: Thysanoptera): convergence of two novel gene boundaries and an extraordinary arrangement of rRNA Genes. Mol Biol Evol. 2003;20(3):362-70.

103. Zhang DX, Hewitt GM. Nuclear integrations: challenges for mitochondrial DNA markers. Trends Ecol Evol. 1996;11(6):247-51.

104. Romanova EV, Mikhailov KV, Logacheva MD, Kamaltynov RM, Aleoshin W Sherbakov DY. The complete mitochondrial genome of Baikalian amphipoda Eulimnogammarus vittatus Dybowsky, 1874. Mitochondrial DNA A DNA MappSeq Anal. 2016:27(3):1795-7.

105. Romanova EV, Mikhailov KV, Logacheva MD, Kamaltynov RM, Aleoshin W, Sherbakov DY. The complete mitochondrial genome of a deep-water Baikalian amphipoda Brachyuropus grewingkii (Dybowsky, 1874). Mitochondrial DNA. 2015. doi:10.3109/19401736.2014.1003891.

106. Black 4th WC, Roehrdanz RL. Mitochondrial gene order is not conserved in arthropods: prostriate and metastriate tick mitochondrial genomes. Mol Biol Evol. 1998;15(12):1772-85. 
107. Campbell NJ, Barker SC. The novel mitochondrial gene arrangement of the cattle tick, Boophilus microplus: fivefold tandem repetition of a coding region. Mol Biol Evol. 1999;16(6):732-40.

108. Ogoh K, Ohmiya Y. Complete mitochondrial DNA sequence of the sea-firefly, Vargula hilgendorfii (Crustacea, Ostracoda) with duplicate control regions. Gene. 2004:327(1):131-9.

109. Arndt A, Smith MJ. Mitochondrial gene rearrangement in the sea cucumber genus Cucumaria. Mol Biol Evol. 1998;15(8):1009-16.

110. Yang J, Ye F, Huang Y. Mitochondrial genomes of four katydids (Orthoptera: Phaneropteridae): New gene rearrangements and their phylogenetic implications. Gene. 2016;575(2):702-11.

111. Bernt M, Braband A, Schierwater B, Stadler PF. Genetic aspects of mitochondrial genome evolution. Mol Phylogenet Evol. 2013;69(2):328-38.

112. Boore JL. The duplication/random loss model for gene rearrangement exemplified by mitochondrial genomes of deuterostome animals. In: Sankoff D, Nadeau JH, editors. Comparative genomics. Dordrecht: Kluwer Academic Publishers; 2000. p. 133-47.

113. Lavrov DV, Boore JL, Brown WM. Complete mtDNA sequences of two millipedes suggest a new model for mitochondrial gene rearrangements: duplication and nonrandom loss. Mol Biol Evol. 2002;19(2):163-9.

114. Dowton M, Campbell NJH. Intramitochondrial recombination - is it why some mitochondrial genes sleep around? Trends Ecol Evol. 2001;16(6):269-71.

115. Bazikalova A. Systematics, ecology and distribution of genera Micruropus Stebbing and Pseudomicruropus nov. gen. (Amphipoda, Gammaridae). In: Galaziy Gl, editor. System and ecology of Crustaceans of Lake Baikal. Moscow: Acad. Sci. Publishing House; 1962. p. 3-140.

116. Bekman MYu. Ecology and production of Micruropus possolskii sow. and Gmelinoides fasciatus stebb. In: Galaziy Gl, editor. System and ecology of crustaceans of Lake Baikal. Moscow: Acad. Sci. Publishing House; 1962. p. 141-56.

117. Vorobiova GA, Matz VD, Shimaraeva MK. Late-Cenozoic paleoclimates in the Baikal region. Russian Journ Geol Geophys. 1995;36(8):82-96.

118. Doyle JJ, Dickson E. Preservation of plant samples for DNA restriction endonuclease analysis. Taxon. 1987;36:715-22.

119. Folmer O, Black M, Hoeh W, Lutz R, Vrijenhoek R. DNA primers for amplification of mitochondrial cytochrome c oxidase subunit I from diverse metazoan invertebrates. Mol Mar Biol Biotechnol. 1994;3(5):294-9.

120. Bolger AM, Lohse M, Usadel B. Trimmomatic: A flexible trimmer for Illumina sequence data. Bioinformatics. 2014;30(15):2114-20.

121. Bankevich A, Nurk S, Antipov D, Gurevich AA, Dvorkin M, Kulikov AS, et al. SPAdes: a new genome assembly algorithm and its applications to single-cell sequencing. J Comput Biol. 2012;19(5):455-77.

122. Altschul SF, Madden TL, Schaffer AA, Zhang J, Zhang Z, Miller W, et al. Gapped BLAST and PSI-BLAST: A new generation of protein database search programs. Nucleic Acids Res. 1997:25(17):3389-402.

123. Langmead B, Salzberg SL. Fast gapped-read alignment with Bowtie 2. Nat Methods. 2012;9(4):357-9.

124. Milne I, Stephen G, Bayer M, Cock PJA, Pritchard L, Cardle L, et al. Using Tablet for visual exploration of second-generation sequencing data. Brief Bioinform. 2013;14(2):193-202.

125. Bernt M, Donath A, Juhling F, Externbrink F, Florentz C, Fritzsch G, Putz J, et al. MITOS: Improved de novo metazoan mitochondrial genome annotation. Mol Phylogenet Evol. 2013;69(2):313-9.

126. Abeel T, Van Parys T, Saeys Y, Galagan J, Van de Peer Y. GenomeView: a nextgeneration genome browser. Nucleic Acids Res. 2012. doi:10.1093/nar/gkr995.

127. Juhling F, Putz J, Bernt M, Donath A, Middendorf M, Florentz C, et al. Improved systematic tRNA gene annotation allows new insights into the evolution of mitochondrial tRNA structures and into the mechanisms of mitochondrial genome rearrangements. Nucleic Acids Res. 2012;40(7):2833-45.

128. Stothard $P$. The sequence manipulation suite: JavaScript programs for analyzing and formatting protein and DNA sequences. Biotechniques. 2000;28(6):1102-4.

129. Supek F, Vlahovicek K. INCA: synonymous codon usage analysis and clustering by means of self-organizing map. Bioinformatics. 2004;20(14):2329-30.

130. Perna NT, Kocher TD. Patterns of nucleotide composition at fourfold degenerate sites of animal mitochondrial genomes. J Mol Evol. 1995;41(3):353-8.

131. Rozas J, Sanchez-DelBarrio JC, Messeguer X, Rozas R. DnaSP, DNA polymorphism analyses by the coalescent and other methods. Bioinformatics. 2003;19(18):2496-7.

132. Abascal F, Zardoya R, Telford MJ. TranslatorX: multiple alignment of nucleotide sequences guided by amino acid translations. Nucleic Acids Res. 2010. doi:10.1093/nar/gkq291.
133. Gouy M, Guindon S, Gascuel O. SeaView version 4: A multiplatform graphical user interface for sequence alignment and phylogenetic tree building. Mol Biol Evol. 2010;27(2):221-4.

134. Posada D. jModelTest: phylogenetic model averaging. Mol Biol Evol. 2008; 25(7):1253-6.

135. Ronquist F, Huelsenbeck JP. Mrbayes 3: Bayesian phylogenetic inference under mixed models. Bioinformatics. 2003;19:1572-4

136. Rambaut A. FigTree-v1.4.2. 2014. http://tree.bio.ed.ac.uk/software/figtree/. Accessed 12 Oct 2014

\section{Submit your next manuscript to BioMed Central and we will help you at every step:}

- We accept pre-submission inquiries

- Our selector tool helps you to find the most relevant journal

- We provide round the clock customer support

- Convenient online submission

- Thorough peer review

- Inclusion in PubMed and all major indexing services

- Maximum visibility for your research

Submit your manuscript at www.biomedcentral.com/submit
) Biomed Central 